\title{
La estética de la naturaleza en Fray Luis de León
}

\author{
LA INTERPRETACIÓN ESTÉTICA, SOCIAL, FILOSÓFICA \\ Y RELIGIOSA DE LA NATURALEZA
}

\section{LA VUELTA A LA NATURALEZA Y SUS IMPLICACIONES ESTÉTICAS Y SOCIALES}

El tema de la naturaleza en Fray Luis de León comprende múltiples perspectivas. El análisis incluye no sólo la investigación de lo que significa la naturaleza en sí misma, sino también las variaciones que se producen en las actitudes vitales y estéticas del hombre al contacto con su significación más profunda. Recuérdese la teoría de Ortega, que ya hemos apuntado, de que el retorno al campo y al mundo exterior es una característica de las épocas en crisis. Nosotros queremos significar que la vuelta a la naturaleza trae también la vuelta a nuevas formas de pensar y de vivir que pueden abarcar los más diversos quehaceres del acontecer humano. Como la naturaleza se carga de densidad ideológica, veremos que hay una vuelta a todo aquello que se asemeja a ella desde el fondo intelectual común. Así encontramos que hay una vuelta típicamente renacenstista a lo primitivo de las cosas, a todo aquello que supone una limpieza radical y algo no contaminado. La razón es que la naturaleza persiste en su estado primitivo y original, tal como salió de las manos de Dios. El contraste entre ese estado de amanecer permanente y el del hombre, viejo y destructor, se resuelve a favor del primero. El hombre es un ser contaminado y contaminador. La naturaleza es la huella y el espejo de Dios porque refleja el primer momento de gloria en que fue creada. Así se comprende el encanto que despiertan en Fray Luis las gracias de los niños, o la sabiduría popular, o la importancia del aseo. El poeta fustigará duramente el uso femenino de los cosméticos, no tanto por motivos de púlpito, cuanto por razones de principios filosóficos: la doncella o la dama que usan y abusan de los cosméticos, encubren la obra de Dios, que es la más auténtica y la más bella. Todo atentado contra lo natural es un atentado contra la verdad y la inocencia primera de las cosas. 
Junto a esta actitud estética impuesta por la significación filosófica, y aun religiosa, de la naturaleza, encontramos otra social y política. Si lo natural de nuestro contorno es lo auténtico, la comunidad humana y el hombre mismo serán tanto más perfectos cuanto más se acerquen a la naturaleza y a sus peculiares formas de vida. Aquí radica la significación de la exaltación de lo pastoril y la alabanza de los rústico y de la vida del campo. Durante siglos el hombre había impuesto sus esquemas al mundo exterior. En el Renacimiento cambiaría totalmente el signo de esta influencia que se acentuará en el Romanticismo. La naturaleza le brinda a Fray Luis la forma de llenar esa apetencia de más ser que encierran las cosas. Es el amor más cabal, el del estilo pastoril, lo que ata con ligadura de oro todo lo existente. El hombre, si quiere serlo de verdad, ha de imitar a la naturaleza. Es más: ha de observarla constantemente, porque en ella está marcado el paso de Dios.

La intelectualización que hace Fray Luis de lo exterior justifica un estudio que integre las implicaciones sociales, políticas y estéticas, que entraña la vuelta al entorno natural del hombre. Esta actitud es, en gran parte, patrimonio del Renacimiento, pero en la obra de Fray Luis toma unas formas singularizadoras que es preciso destacar.

\section{Lo pastoril}

Como indica Margot Arce de Vázquez en su libro sobre Garcilaso, lo pastoril procede de una divinización previa de la naturaleza. La literatura de pastores supone una actitud que enraiza, en el fondo con la fascinación del descubrimiento del universo sobre la base de una de las dos vertientes del pensamiento platónico: la de la perfección de las cosas como reflejo y grado último de la divinidad.

La literatura pastoril, que comienza con una inspiración virgiliana, se va cargando de densidad y filosofía a medida que avanza el Siglo de Oro. Media un abismo entre la pastoral de Garcilaso o del Encina y el tercer diálogo satírico de Antonio de Torquemada. La naturaleza es el soporte de este tipo de literatura y el hontanar secreto por el que fluye una corriente secréta de ideas, del objetivismo de Santillana y el juego de los nobles a hacer de pastores en el siglo XV llegamos a una intensa interiorización del tema pastoril que se hace fundamento para la expresión de las más íntimas apetencias del hombre. La creación literaria se convierte así en la manera sutil que utiliza el artista para decir todo aquello que desea, pero que resultaría peligroso enunciar claramente. Fray Luis tenía que entusiasmarse con este género literario que le ofrecía la oportunidad de plasmar ideas comprometidas y que llenaba, al mismo tiempo, la urgente codicia de sosiego que sentía. Veremos que hay un sistema de convicciones fundamentales en esta vuelta a la naturaleza.

A diferencia de la pastoral italiana, la española se carga de existencialidad. Lo pastoril se convierte en una forma de ser. Lo que menos importa es 
que se trate de unos pastores idealizados e inexistentes. Efectivamente, los personajes son creación exclusiva del artista. Pero esto importa poco. Si comparamos los personajes de la pastoral con los de la realidad fáctica, encontraremos que no se alejan de ella más que los personajes desrealizados de muchas novelas actuales. Se explica que Fray Luis atacara los libros de caballería, pero se sientiera atraído por los de tema pastoril. El género literario le brindaba el medio para la comunicación de un mensaje y para el alivio emocional del corazón. Lo mismo que a Don Quijote, por loco, al personaje pastoril, por idealizarlo, no se le tiene en cuenta, aunque diga las verdades más palmarias. Es más: los personajes de la pastoral no expresan ideas directamente, sino que las ponen en acción. Con ello la peligrosidad de los conceptos se diluye más y aumenta la posibilidad de expresar las más graves ideas. Lo pastoril deviene así a un sistema comunicativo minoritario. Pero es eficaz. Veremos que, en muchas ocasiones, Fray Luis contrapone la vida natural de los pastores a la urbana desde la perspectiva de un filósofo moral; mas estas mismas ideas se proponen activamente en el comentario al Cantar de los Cantares que nuestro escritor toma como una égloga amorosa entre Salomón y la hija del faraón de Egipto. Si atendemos a la significación ideológica de lo pastoril en la obra de Fray Luis, comprenderemos mejor cómo los inquisidores debían de intuir en el comentario del Cantar algo más que el incumplimiento de la prohibición de traducir las Escrituras Sagradas a la lengua romance. Mirando bajo el haz de las cosas, el Cantar de los Cantares y su comentario significan la expresión velada de ideas y actitudes que contradecían a las que oficialmente y socialmente se imponían en la España del siglo XVI. A las formulaciones directas, de ensenanza moral, se une la corriente vaga e imprecisa de la significación del conjunto de la obra. Sin saber concretamente por qué, tenía que ser grande el desasosiego de un vigilante del Santo Oficio al leer el comentario de Fray Luis. Intentaremos aclarar las causas. Y que en la obra del poeta de Salamanca hay muchas actitudes conflictivas bajo la forma literaria y la llamada a la naturaleza lo muestra el hecho de que en 1609, muerto ya el escritor, se le acusa de ir contra los estatutos de pureza de sangre en unos párrafos «Rey de Dios». La alusión nos parece clara ahora, pero el tiempo que tardó en descurbirse el agudo ojo inquisitorial, manifiesta hasta qué punto el género literario podía ocultar las ideas más explosivas.

\section{A. El vivir en sí mismo y la libertad}

La vuelta a la naturaleza desde la perspectiva del género pastoril tiene un trasfondo mucho más complejo que desde la perspectiva ética que opone los valores del campo a los de la ciudad. Si consideramos el Cantar de los Cantares, veremos que supone un énfasis sobre el amor y la inspiración primera de nuestro poeta, la Biblia. El interés constante de Antonio de Torquemada que 
ya los personajes de la Biblia vivieron al estilo pastoril, lo encontramos también en la obra de Fray Luis de León '.

El Comentario al Cantar de los Cantares, que entendimos en un principio como un desafío a la capacidad intelectual del poeta, se ve enriquecido al tomarlo como una necesidad de desahogo de su propia personalidad. Si en el orden filosófico lo pastoril procede de una divinización del contorno exterior, en el orden vital procede de una necesidad imperativa de sosiego. Américo Castro interpreta esta actitud, a la luz de la existencia de los hebreos, como una vuelta a la naturaleza para vivir consigo mismo. En la interpretación del tema del retiro en la poesía luisiana ya indicamos cómo nos parecía que ello significaba algo sumamente positivo, una necesidad urgente de conocimiento propio y de ser en sí mismo frente a la dispersión del ser en otro, tal como acontecía en la vida urbana. Esta es también la primera idea de Fray Luis frente a lo pastoril: sus personajes hacen la vida de sosiego que él desea para sí mismo. Es la secreta y sutil envidia que muchas veces siente el intelectual por aquellos que han podido evadirse de los negocios ciudadanos. Este mismo fenómeno de cansancio y apetencia de sosiego y naturaleza se produce hoy entre las gentes de nuestra sociedad. $Y$ algunos intentan realizar el sueño.

Este sosiego que la vida pastoril significa para Fray Luis no es la pasividad perezosa de los señores y los nobles, que él tanto fustiga, como veremos, sino la actitud esencial de quien necesita vivir en sí mismo. Frente al vivir desviviéndose del hombre en la ciudad tenemos el vivir viviéndose de lo pastoril. No se identifica con la inactividad de los señores ni con la vida real de las gentes del campo. Habrá que tener muy en cuenta la angustia permanente que encuentra Américo Castro en los hebreos del siglo XVI español. Fray Luis es completamente consciente de la triste situación de éstos, y rompe veladas lanzas a su favor. Como sugiere M. Bataillon, puede que la melancolía que respiramos en muchos escritores del Siglo de Oro se deba tanto a una base renacentista como judía. El hecho es que nuestro escritor encuentra en la vuelta a la naturaleza de lo pastoril la realización del deseo de sosiego que él tanto apetecía. Si en la vida ciudadana percibimos el cambio de las cosas exteriores, que nos enriquece por fuera y nos empobrece por dentro, en la vida pastoril encontramos la serenidad necesaria para vivir plenamente. El campo semántico del sosiego es el más fecundo en los comentarios luisianos sobre la vida pastoril. La angustia que supone la sociedad urbana, donde el poeta se siente desgarrado entre su ser profundo de cristiano y hebreo y la existencia difícil en lo

1. «Mas, porque, Marcelo, decís de lo que es ser pastor y del caso que de los pastores la poesía hace, mucho es de maravillar con qué juicio los poetas, siempre que quisieron decir algunos accidentes de amor, los pusieron en los pastores, y usaron más que de otros de sus personas para representar esta pasión en ellas; que así lo hizo Teócrito y Virgilio. Y ¿quién no lo hizo pues el mismo Espíritu Santo, en el libro de los Cantares tomó dos personas de pastores para por sus figuras de ellos y por su boca hacer representación del increíble amor que nos tiene?» (Op. cit. 445). Pastor. 
exterior que le impide la realización de sus valencias personales, es superada por una vuelta a lo primitivo de la naturaleza, tal como se da en el vivir pastoril. En él no existen ni las clases sociales ni la honra ni las diferencias de religión. Allí el amor, como señor supremo del universo, lo armoniza todo, y el hombre no es lo que heredó de sus padres, sino lo que de él han hecho sus propias obras.

El sentido naturalista del amor pastoril en que el amante pierde el alma en el amado viene a concretar las condiciones fundamentales de la estética luisiana: por un lado, la circunstancia conflictiva del vivir desviviéndose y, por otro, la tendencia a la unidad de las cosas. Al vivir desviviéndose del amante corresponde un mayor ser en el amado que capta otra alma por medio del amor. La Biblia avala la interpretación unitaria y angustiante de Fray Luis.

El tema de la libertad que estudiamos en el motivo del retiro, aparece aquí también. La idea de libertad es fundamental para la de sosiego, y subyace a toda estética de vuelta a la naturaleza. A ellas va unida la paz. Libertad, sosiego y paz fundamentan ideológicamente la actitud naturalista de Fray Luis de León ${ }^{2}$. Es la misma idea que expresa la pastora Marcela, del Quijote: «Yo nací libre, y para vivir libre escogí la soledad de los campos». Como comenta Américo Castro sobre estas palabras, «ni más ni menos que Don Quijote, que huye de los campos como una peste» ${ }^{3}$.

Es interesante hacer notar todas estas condiciones que el poeta encuentra en la naturaleza. Todas de carácter positivo. Esto le servirá después para contraponer esta vida y estas actitudes a las de las gentes de la ciudad, pero no a todas, sino a aquellas que las gobiernan, como veremos más adelante.

\section{B. El ser y el hacer. La proyección biográfica}

En la pastoral el hombre aparece básicamente bueno. Ocurre lo contrario en el comentario que Fray Luis hizo al Libro de Job. La idea de la bondad y perfección primeras del mundo está presente en la obra luisiana. Por eso Cristo vive en los campos. El poeta encuentra en la ficción pastoril al hombre que está buscando. La creación literaria, repetimos, viene a concretar la figura optimista que el escritor tiene en su mente. La bondad primera de la naturaleza, que lo es porque así salió de las manos de Dios, es comunicada, por gracia y virtud de la creación artística, al hombre, que es el único ser que rompe la armonía del universo y se aparta del fin para el que fue destinado. En toda la

2. «... y de toda esa paz nace al andar el hombre libre y bien animado y seguro; así de todo aqueste amontonamiento de bien, que es gozar el hombre de sí y poder vivir consigo mismo, y en no tener miedo a entrar en su casa».' (Op. cit. 606). Príncipe de la paz.

3. A. CASTRO, «Hacia Cervantes», Madrid 1960, pág. 249. 
pastoral subyace una estética de la armonía. Todo está bien hecho. Las cosas han de "consonar» entre sí. Nunca se encuentra el hombre más cerca que en la creación pastoril. Se produce una simbiosis entre la bondad de la naturaleza y el hombre. A la idea platónica de las cosas como reflejo de la divinidad se une la experiencia bíblica de unas gentes que eran pastores o labradores, y que dejaban el gobierno para regresar a la tierra de donde salieron.

La idealización de lo pastoril, al suprimir el paisaje concreto, lo que hace es difuminar las fronteras entre la naturaleza y el hombre y su vida. Ésta se siente como una prolongación de aquélla. Hay en ello la secreta convicción, que llegaría al Romanticismo, de que el hombre es básicamente bueno y que sólo la sociedad en que vive le hace perverso. Si la pastoral española supera en densidad de pensamiento y significación a la italiana o a la francesa es porque se siente más profundamente la escisión y la lucha entre el hombre y la sociedad que le rodea. La sociedad florentina había hecho del platonismo un sistema de vida; la española del siglo XVI no tiene un auténtico estilo de acción, aparte el religioso y aventurero, puesto que las gentes de más valía se escinden entre el ser y el hacer. El descendiente de conversos, por muy cristiano que sea, ha de ocultar su más hondo ser y alejarse en el hacer de todo aquello que recuerde su antiguo linaje. Se comprende la escisión del intelectual en unos momentos en que la agudeza de ingenio era conocida como cosa de hebreos. $Y$ ello hasta tal punto que, en algunas ocasiones, se acusaba de judaísmo a determinadas personas por el sólo hecho de ser inteligentes o de haberlo sido alguno de sus antepasados. La pastoral era un estilo de vida que armonizaba el ser y el hacer y donde el amor, símbolo de la unidad de los seres, lo regía todo, como en los últimos versos de la «Divina Comedia».

En el género pastoril es necesario tener en cuenta la biografía del escritor, precisamente porque significa la superación del yo angustiado por la creación literaria, actitud que ya estudiamos en la oda a Juan de Grial desde un punto de vista más humanístico, menos agitado.

En el nombre de «Pastor» Fray Luis exalta el estilo pastoril. Cada palabra tiene un mundo de resonancias detrás de ella. Toda una filosofía y una concepción de la vida se asoman a estos párrafos. Lo que se predica es el deseo de naturaleza como el deseo de algo primigenio y noble, donde sólo anida la verdad de lo auténtico.

«Porque lo primero, la vida pastoril es vida sosegada y apartada de los ruidos de las ciudades, y de los vicios y deleites de ellas. Es inocente, así por esto como por parte del trato y granjería en que se emplea. Tiene sus deleites, y tanto mayores cuanto nacen de cosas más sencillas y más puras y más naturales: de la vista del cielo libre, de la pureza del aire, de la figura del campo, del verdor de las yerbas y de la belleza de las rosas y de las flores. Las aves con su canto y las aguas con su frescura le deleitan y sirven. $Y$ así por esta razón, es vivienda muy natural y muy antigua entre los hombres, que luego en los primeros de ellos hubo pastores; $y$ es muy usada por los mejores hombres que ha 
habido, que Jacob y los primeros patriarcas la siguieron, y David fue pastor, y es muy alabada de todos, que, como sabéis, no hay poeta, Sabino, que no la cante y alaben ${ }^{4}$.

Los adjetivos nos dan la clave de la densidad ideológica de lo que significa lo pastoril para Fray Luis : vida sosegada, inocente; cosas sencillas, puras y naturales, cielo libre, hombres mejores. Las últimas frases nos dan el sentido vital y existencial del pensamiento luisiano sobre la vuelta a la naturaleza de lo pastoril: los hombres mejores que han existido han llevado este género de vida sosegada y natural, por tanto, la perfección del hombre será tanto mayor cuanto más se acerque a este género de vida. Es permanente en la obra luisiana la idea de la comunicación entre todo lo existente. Y como el poeta persigue siempre el hacer un hombre mejor, al vincular la vida de la naturaleza a los hombres mejores la convierte en un paradigma al que contrapone la vida de los hombres que no llegan a ser ni buenos siquiera. Entra dentro de la estética de Fray Luis, sobre todo en Los Nombres de Cristo, el proponer primero la descripción de un hecho, una actitud o una idea con la que contrasta otro muy diferente. El poeta es consciente de este uso que hace del contraste para que las ideas aparezcan más claras. Al indicar que «no hay poeta que no cante esta vida» adivinamos también el nudo secreto que hay entre la naturaleza y la poesía, tal como lo estudiamos en Los Nombres de Cristo. El poeta, que es un profeta, ha de cantar la naturaleza y los valores básicos que se vinculan a ella. Fray Luis localiza en el campo todos aquellos valores por los que ha luchado, y que le faltan en la ciudad. La cárcel y dos procesos inquisitoriales, la envidia y la mentira están destrás del párrafo citado. El Cantar de los Cantares santificaba este género de vida.

\section{La apetencia de más ser y la unidad por el amor}

La apetencia de más ser en que el poeta ve envuelto el cosmos, se desarrolla en el hombre de dos maneras fundamentales: una que atañe a la captura intelectual de las cosas, como veremos más adelante, y otra que atañe a la parte emocional, y que tiene su expresión más intensa en la unión continua -anihilante y enriquecedora al mismo tiempo- que busca el amor. Fray Luis encuentra en el estilo pastoril la más exacta expresión de este deseo de ser más que conmueve las raíces de lo existente. El erotismo del Cantar de los Cantares aflora sobre una bellísima concepción de la unidad que el poeta expresa repetidas veces. Sobre la base filosófica de la armonía y de la unión del cosmos y el aval religioso Fray Luis desarrolla la captura de otro ser por el amor de acuerdo con las tensiones unitarias que se dan en el estilo pastoril y en la vida del campo. Así, todo amor que pretende ser auténtico en la compleja gama de posibilidades que encierra, ha de asemejarse al que se da en la naturaleza. De ahí

4.. Op. cit. 444-445. Pastor. 
que en estas relaciones respiremos un velado panteísmo, una oculta identificación del hombre con el universo. La naturaleza no es sólo el marco que establece la captura de lo otro, sino que es parte integrante del sentimiento de unidad, porque únicamente en ella puede realizarse cabalmente. O lo que es lo mismo: sólo en una vida de sosiego, libertad y sinceridad se da la auténtica comunicación de los seres. Esto es lo que se quiere decir. Y es tan verdadero hoy como entonces. El ropaje literario cubre estas ideas que dan trascendencia y profundidad al tema. Los genios obran siempre para la eternidad.

En este afán por acercar unas cosas a otras es básico el principio que para poder decir con verdad que dos cosas son una, basta que sean muy semejantes. Fray Luis sigue en ello la forma común de hablar de las gentes. Lo que interesa es hallar los puntos clave de esa semejanza de las cosas para hacer posible la unión. Los puentes que tiende el amor, cuando es real y sincero como el de la pastoral, unen unas orillas a otras porque «quien se inclina mucho a una cosa, quien piensa en ella de continuo, quien conversa siempre con ella, quien remeda, fácilmente queda hecho ella misma»" ${ }^{5}$. El amor procede de un deseo de hermosura, conforme a la teoría platónica ${ }^{6}$, y tiende a la unidad ${ }^{7}$. $\mathrm{El}$ amor es darse todo y recibirlo todo ${ }^{8}$. Es una de las dos alas que tiene el hombre para poder volar a la captura de más ser. La otra es el entendimiento. Esta unión sólo se realiza perfectamente en la vida de la naturaleza. Así, las expresiones de amor de la Esposa al Esposo las significa Fray Luis en un comentario que nos recuerda el tono de divinización y extremecido naturalismo panteístico de la Celestina. Dice la Esposa-pastora:

«Si yo soy hermosa, como tú dices, amor mío y si tal parezco, tú no me pareces a mí menos bien; y hermoso eres con la misma hermosura, y gracioso y salado más que la gracia; y no sólo tú eres sal, mas también todas tus cosas por ser tuyas, por el semejante, son hermosas y lindas; la cama cubierta de flores, y la casa, rica y hermosamente edificada; al fin, todo es lindo, y tú más que todo ello" 9 .

Todo este párrafo está transido de una concepción platónica del amor y la belleza. El amado es superado hasta ser igual que la hermosura misma. Y no sólo lo exterior, sino lo interior es superado también la gracia, en lo que consiste la hermosura auténtica. Todo lo funde el amor en una perfecta unidad. Es una suerte de divinización de las cosas. El amor borra las fronteras entre el yo, el tú y lo exterior. Todo se siente como la prolongación de un úni-

5. Op. cit. 684. Hijo de Dios.

6. Op. cit. 87. Cantar 1,15.

7. «Porque el amor, como platicábades ahora, Juliano, y Sabino, es unidad; y cuanto es mejor y mayor la unidad, tanto es mayor y más excelente el amor. Por donde, cuanto por más particulares maneras fueren uno mismo entre dos entre sí, tanto sin duda ninguna se tendrá más amorn Op. cit. 629. Esposo.

8. Op. cit. 178. Cantar 7,10

9. Op. cit. 86. Cantar 1,15 . 
co ser universal. Se difuminan los límites entre lo objetivo y lo subjetivo. El amante se pierde en el amado con todas las cosas que le rodean. Esta prolongación se percibía en la naturaleza mejor que en ningún otro sitio. El sentimiento de fascinación ante la naturaleza halla su realización en la aprehensión de lo otro, tal como ocurre en el amor pastoril. Lo que nos interesa destacar es que esta posibilidad de ser más por medio de la función unitiva del amor se da exclusivamente en la vida del campo. El contacto con el entorno natural devuelve al hombre a un estado primitivo de infancia donde se dan la mano la pluralidad de las cosas, y donde se siente la atracción que produce la unidad del todo. Aquí está una de las bases conceptuales de la exaltación que Fray Luis hace de lo pastoril. La armonía del cosmos, que en el campo se siente más cercana comunica al hombre su apetencia de unidad. La verdadera unión sólo puede hallarse en la soledad de los campos. La unidad sigue al sosiego y al vivir en sí mismo. En la ciudad el hombre se encuentra alienado. En la vida del campo hay un proceso de interiorización que lleva al hombre al ser primero de las cosas, al lugar en que ellas son lo que son, es decir, armonía y amor. Es el hombre quien, por el pecado, produjo la desarmonía en el mundo. Volver a la naturaleza es volver a la inocencia primera. Esta inocencia permite al hombre abrirse a las verdaderas realidades. Por contraste, no existe en la ciudad ese amor auténtico $y$, por tanto, el hombre no cumple en ella su condición de microcosmos, de mundo pequeño y ordenado, según la propia acepción luisiana. La ciudad y el campo se diferencian aquí radicalmente. No es de extrañar la permanente alabanza del campo que hace nuestro autor. Hay en ella demasiado trasfondo filosófico. Fray Luis, que tradujo la elegía III del libro II de Tibulo «Rura tenent» con un primer verso único, sin par:

«Al campo va mi amor, y va a la aldea;

el hombre que morada un punto solo

hiciese en la ciudad, maldito sea».

nos dice ahora la causa de sus preferencias por el amor al estilo pastoril. Porque el amor de la ciudad «tiene poco de verdad y mucho de arte y torpeza» y continúa:

«mas el pastoril, como tienen los pastores los ánimos sencillos y no contaminados con vicios, es puro y ordenado a buen fin; y como gozan del sosiego y libertad de negocios que les ofrece la vida sola del campo, no habiendo en él cosa que les divierta, es muy vivo y agudo. Y ayúdanle a ello también la vista desembarazada, que de continuo gozan, del cielo y de la tierra y de los demás elementos, que es ella en sí una imagen clara, o por mejor decir, una como escuela de amor puro y verdadero. Porque los demuestra a todos amistados entre sí y puestos en orden, y abrazados, como si dijésemos, unos con otros, y concertados con armonía grandísima, y respondiéndose a veces y comunicándose sus virtudes y pasándose unos en otros y ayuntándose y mezclándose todos, y con su mezcla y ayuntamiento sacando de continuo a luz, y produ- 
ciendo los frutos que hermosean el aire y la tierra. Así que los pastores son en esto aventajados a los otros hombres» ${ }^{10}$.

Si antes no había dicho que la vista del cielo libre y del aire, y la belleza de las rosas y el canto de las aves era deleite para quienes viven al estilo pastoril, ahora nos indica cómo esos elementos colaboran a la perfección del hombre. Es algo definitivo, el campo es una escuela de amor puro y verdadero. Allí hemos de acudir para aprender. Recordemos, de paso, la revolución copernicana que se había operado en la forma de mirar la naturaleza. La Edad Media la había aprisionado en símbolos. La nueva forma proviene del Humanismo renacentista. Como Leonardo de Vinci observaba extasiado el vuelo de los pájaros y estudiaba su máquina voladora conforme a lo visto en una naturaleza divinizada, Fray Luis de León acude al campo para aprender y reflejar en el orden ético y existencial lo que ve en el mundo natural. Él ha observado cómo los frutos que hermosean el aire y la tierra son producidos por el esfuerzo amoroso y unido de todos los elementos que organizan el cosmos. De ahí proviene la belleza de las flores y de las rosas. Por estar la naturaleza en la pastoral tal como salió de las manos de Dios, puede ser una escuela de amor y verdad. El hombre encuentra en ella lo más original de la creación. Fray Luis dejó escrita la superioridad del estilo de vida del campo sobre el de la ciudad en unas páginas lapidarias, definitivas:

«Porque puede ser que en las ciudades se sepa mejor hablar; pero la fineza del sentir es del campo y la soledad» ${ }^{11}$.

Pero es que, además, el amor es lo más cercano a la vida del cielo. Parte Fray Luis de una idea bellísima, y es que la relación de dos enamorados es lo más semejante a Dios, que es deseo de las cosas y amor, según el Evangelio:

«... porque, cierto es la más feliz vida que acá se vive, la de dos enamorados, y es muy semejante y muy cercano retrato de la del cielo...» ${ }^{12}$.

Sólo la sublimación del amor en lo religioso, en Dios, podía superar este maravilloso sentido del amor. Y todo este sentido unitario y total del sentimiento amoroso se da, de una forma perfecta, en la vida del campo y de los pastores. Nada hay en el mundo que refleje mejor que la naturaleza la vida religiosa. Ella se convierte en colaboradora de Dios en la vuelta del hombre a lo divino. Todo está empapado de religiosidad en nuestro poeta. La vida y el amor en la naturaleza son la vida y el amor en Dios. La carga intelectual que pone Fray Luis en ello es muy grande. Además de la veracidad y la bondad destaca el sentido unitario, capturador de más ser del amor. Si la perfección de las cosas consiste en imitar a Dios que lo contiene todo en sí, tenemos que «el que ama y es amado, ni desea más de lo que ama, ni le falta nada de lo que

10. Op. cit. 446. Pastor.

11. Op. cit. 445. Pastor.

12. Op. cit. 179. Cantar 7,10 . 
desea» ${ }^{13}$. Comprendemos ahora que el deseo de retiro y soledad del campo, que veíamos al tratar de las poesías, es algo totalmente alejado del sentimiento horaciano. Una serenidad a rebosar de riqueza era lo que cautivaba a Fray Luis en su pensamiento sobre la naturaleza: la angustia, el desasosiego y la escisión interior superados por la comunicación totalizadora que se da en el sentimiento amoroso de la pastoral. El poeta es consciente de los principios filosóficos en que se basan sus ideas. Hay un párrafo que nos lo demuestra. De los dos oficios del alma que, según la tradición platónica, son el de sustentar al cuerpo y el de contemplar las cosas, el enamorado sólo ejercita la segunda función, contemplando siempre a la amada, y olvidándóse del cuerpo, y añade nuestro escritor: «esto así presupuesto simplemente y sin filosofar en ello más nos declara la grandeza del amor...» ${ }^{14}$.

Para comprender la significación que tiene el situar el amor auténtico en la convivencia con la naturaleza, tenemos que pensar en toda esta complejidad de pensamiento platónico que tiene como base. Si el deseo de soledad en el campo significa, por un lado, una realización propia lejos del desvivirse de las ciudades y el elemento cambiante de las cosas, por otro significa la realización de un deseo de ser más y de "consonar» con la armonía del universo por medio de la función unitaria del amor. Todo ello sobre la base de que la naturaleza refleja a Dios más que el hombre por hallarse en el estado primitivo en que salió de sus manos.

\section{La interpretación política}

La creación literaria al estilo pastoril cumple una función muy sutil que ya hemos apuntado: el escritor vierte a través de ella ideas sobre el gobierno, las clases sociales y la organización de la sociedad en que vive. El recurso vedado de la forma literaria ha sido utilizado con frecuencia para decir todo aquello que resulta comprometido decir abiertamente. Como indica Américo Castro, la alabanza de la vida de aldea había servido antes para expresar la enemistad de los humildes contra los poderosos. En el caso de Fray Luis hay que atender a su ascendiente hebreo. Se expresan aquí los temas más importantes que planteaba la situación conflictiva del descendiente de conversos. Téngase en cuenta que Fray Luis fue acusado oficialmente, varias veces, de la tendencia judaizante de sus escritos y opiniones por ser descendiente de conversos. Es decir, que el hecho de su origen hebreo estaba bien presente en su vida, puesto que sus enemigos - y tenía muchos- procuraban recordárselo continuamente. Ya en 1567, al formarse la comisión que había de entender en la Biblia de Vatablo, que iba a publicar el editor salmantino Portonariis, y de la que formaba parte Fray Luis, se le acusó de judaizante. Basta releer los do-

13. Op. cit. 179-180. Cantar 7,10.

14. Op. cit. 136-137. Cantar 5,3. 
cumentos de su proceso inquisitorial para darnos cuenta de que su ascendiente hebreo está presente en muchas páginas.

Fray Luis de León era profundamente cristiano, pero no toleraba la injusticia. Explicó unas magníficas lecciones sobre leyes en la cátedra de Durando de 1570 a $1571{ }^{15}$ que se encuadran dentro de la gran tradición jurista de nuestro Siglo de Oro. Pero en las páginas castellanas en prosa hay mucho más. En ellas, más que al catedrático vemos al hombre que siente la desigualdad y las leyes absurdas de los príncipes. Es decir, que mientras en el Tratado De legibus sus explicaciones, aunque atrevidas, caen dentro de aquella eclosión del Derecho en el Siglo de Oro, en las obras castellanas y especialmente bajo el ropaje de lo pastoril y lo rústico, vemos muchas opiniones y actitudes que, sin duda, hubieran sido materia fácil para la Inquisición. Hay en estas ideas dolor y amargura. El poeta expresa algo que él ha sentido o siente. De ahí el tono existencial que observamos en ellas.

En general, el sentimiento de una vuelta a la naturaleza matiza todas estas opiniones dentro de un mismo contexto: el hombre vale por lo que él es y por lo que de él han hecho sus obras. De aquí el afán continuo por volver a la naturaleza, a lo primitivo de las cosas. Los años y las leyes escritas habían convertido en un deshonor el hecho de ser hebreo. Hasta los Reyes Católicos no se toma en serio la Inquisición. Por obra y gracia de las leyes escritas de los príncipes, los que antes eran honrados se convierten en vergüenza y desdoro de la sociedad. Es necesario volver al amor sin fronteras de razas o religiones del Cantar de los Cantares, o del estilo pastoril; es necesario volver a lo auténtico, a la sencillez de la naturaleza. Ella es una escuela de verdad y de amor. Sobre esta base Fray Luis ataca, por contraste, todas aquellas leyes, opiniones e instituciones que no se acercan al modelo de estilo pastoril.

Ya en el siglo XV los nobles se sienten atraídos hacia lo rústico por el desencanto de las cosas humanas. Se había operado una crisis del papel de la Providencia en el mundo, tal como había sido entendida en la Edad Media. Anuncia ya el Humanismo y las ideas renacentistas. Frente al desencanto de las grandezas humanas adquiere papel preponderante la fortuna y el tema de «ubi sunt». Es entonces cuando los nobles comienzan a jugar a pastores y pastoras. Aquí encontramos a Santillana y Juan de Mena. Encina compara ya el gobierno con el oficio de pastor y la ejemplaridad de Cristo. M. Bataillon nos indica cómo Cipriano de la Huerga, maestro de Fray Luis de Alcalá, en un discurso compara a Carlos V con el Divino Pastor ${ }^{16}$. En la misma línea, está el soneto de Hernando de Acuña. Lo que hace Fray Luis es proponer el gobierno del estilo pastoril como ejemplo para los reyes. Parte de la idea de que el gobierno de Dios es apacentar y llevar a los fieles como lo hace el pastor con

15. V.: Fray LuIS de LeÓN, «De legibus», Madrid 1963. Edición de Luciano Pereña.

16. V.: M. BATAILlon, «Varia. Lección de Clásicos españoles», Madrid 1964. 
sus ovejas ${ }^{17}$. Partiendo de esta imagen, que ya fue usada por los clásicos, y que está avalada por las palabras de Cristo en el Evangelio, Fray Luis expondrá sus ideas más sentidas sobre el gobierno y la sociedad en que vive. Así, el estilo pastoril, que comenzó siendo un refugio de la dispersión ciudadana para encontrarse uno mismo en el sosiego del espíritu y poder después salir a la búsqueda de más ser por medio de la condición unitaria del amor, se enriquece ahora con una base ideológica de amplia proyección social. Viene a confirmar, una vez más, la complejidad, amplitud y variedad de perspectivas que encontramos en el tema de la naturaleza en la obra luisiana.

Una de las características del estilo pastoril es igualar las clases sociales de tal forma que el noble parece un pastor y el pastor un noble. En el Cantar de los Cantares Fray Luis ahonda mucho más y va más lejos. Las condiciones peculiares de los personajes de esta égloga se prestaban a un ataque al determinismo de sangre y a un énfasis en la igualdad fundamental de todos los hombres. Porque el pastor-esposo de esta obra es Salomón, rey del pueblo escogido, y la pastora-esposa era la hija del Faraón, es decir, hija de la gentilidad. Y sin embargo, cuando la esposa está en Jerusalén, la ciudad escogida, es ya una vecina más de ella porque el amor ha borrado todas las fronteras, incluso la religión. La interpretación que hace Fray Luis del versillo «media charitate constravit propter filias Hierusalem», es "y en medio de él se asentó el amor de las hijas de Jerusalén». Salomón ha hecho un bello trono para sí «en medio del cual él se entró y está allí encendido de amor por una de las hijas de Jerusalén, que era su esposa, la cual, aunque fuese extranjera de nación, estaba ya avecindada y hecha ciudadana de Jerusalén por haberse casado con el rey de ella" ${ }^{18}$. Ciertamente, parece que la explicación de Fray Luis dista mucho del versillo original. El poeta deja bien claro que la esposapastora era extranjera y, por tanto, pagana. Sin embargo, es ya una más entre las gentes del pueblo de Dios. Muy diferente era la situación en España a este respecto.

En el estilo pastoril no hay diferencias de raza, religión y país. Si pensamos en lo que significaba - y significa - para los judíos el casarse con un gentil, comprenderemos mejor la honda significación de este comentario luisiano. Porque en el Siglo de Oro el mesianismo hispánico era, en gran manera, una herencia del mesianismo hebreo. Si repasamos con detenimiento la historia, veremos que las expresiones más encendidas de mesianismo, sean del orden que fueren, han sido lanzadas por gentes de raza hebrea. Lo que ocurría en el Siglo de Oro español, es que se habían trastocado los papeles: la nueva Jerusa-

17. «Y como Platón dice del oficio de rey, que ha de ser de pastor, así como llama Homero a los reyes, porque ha de ser para sus súbditos todo, como el pastor para sus ovejas lo es, porque él las apacienta y las cría y las cura, y las lava y las trasquila y las recrea, así Dios será entonces con su dichoso ganado muy más perfecto pastor...» (Op. cit. 580) Rey de Dios.

18. Op. cit. 114. Cantar 3,10. 
lén era entonces la Iglesia de Roma, y el pueblo escogido era el español. Los españoles del XVI tenían conciencia de obrar para la Historia. Fray Luis mismo participaba de ese mesiansimo, como lo prueba su interpretación del Libro de Job y el Abdías en términos escatológicos referidos al descubrimiento de América. Y que el poeta de Salamanca pone mucho de sí mismo en sus comentarios nos lo muestra una nota que nos sugirió el P. Marcelino Gutiérrez. En un manuscrito de 1589, perteneciente a la Real Academia de la Historia, al exponer Fray Luis el comentario al versillo del «In Abdiam prophetam», «Et transmigratio Hierusalem, quae in Bosphoro possidebit civitates Austro» hay una nota manuscrita que le acusa de violentar el texto para hablar de los judíos. Más adelante, el anotador anónimo dice que la venida a España de los judíos no fue providencial, como piensa Fray Luis, sino para la perdición del país ${ }^{19}$.

Fray Luis de León pone mucho de sí mismo en sus comentarios. No andaba muy desarcertado Álvaro Picario cuando en 1609 acusaba a nuestro poeta de trastocar muchos pasajes para interpretarlos según su propia conveniencia. Y no es sólo esto. Fray Luis se expresa claramente cuando al hablar del amor pastoril comenta a propósito del Cantar que «el amor verdadero no mira en puntillas de crianza, ni en pundonores, ni espera a ser convidado primero, antes él se convida y ofrece» ${ }^{20}$. Américo Castro ha estudiado la trascendencia de lo que significa la honra y la opinión en el Siglo de Oro en función de la situación conflictiva entre cristianos viejos y nuevos. Bataillon cuenta el caso de un sujeto de Segovia a quien lo único que preocupaba al morir era que sus hijos no se casasen con cristianas viejas. El amor pastoril era la parcela humana en que las cosas estaban en su punto. Siempre la preocupación por volver a las cosas en sí mismas, a la naturaleza, donde no existen ni la herencia de los antepasados ni los sambenitos ${ }^{21}$.

En el estilo pastoril no existen determinismos de sangre. Cada uno es responsable de sus obras, no de las que hayan hecho sus antepasados. Aquí no cuentan éstos. Fray Luis concibe el reino de Dios a manera pastoril, y el gobierno de los príncipes será tanto más perfecto cuanto más se acerque a este tipo de gobierno. Hay un párrafo bellísimo en que el poeta expone las condiciones del gobierno al modo de la pastoral. Por contraste, hay que suponer que éstas no se dan en el gobierno de los príncipes, como afirma repetidas veces:

«Y sea la tercera la que toca a su oficio, que aunque es oficio de gobernar y regir, pero es muy diferente de los otros gobiernos. Porque lo uno, su gobierno no consiste en dar leyes ni en poner unos mandamientos, sino en apacen-

19. MarCELINo GutierReZ, "Fray Luis de León y la Filosofía española del siglo XVI». Madrid 1891, págs. 381-382.

20. Op. cit. 77. Cantar 1,6 .

21. Op. cit. 179. Cantar 7,10. 
tar y alimentar a los que gobiernan. Y lo segundo, no guarda una regla generalmente con todos y en todos los tiempos, sino en cada tiempo y en cada ocasión ordena su gobierno conforme al caso particular del que rige. Lo tercero, no es gobierno el suyo que se reparte y ejercita por muchos ministros, sino él solo administra todo lo que a su grey le conviene; que él la apasta, y la abreva, y la baña, y la trasquila, y la cura, y la castiga, y la reposa y la recrea, y hace música y la ampara y defiende. $Y$, últimamente, es propio de su oficio recoger lo esparcido y traer a un rebaño a múchos, que de suyo cada uno de ellos caminará por sí» ${ }^{22}$.

Así pues, las condiciones del gobierno pastoril son, primero: más que dar leyes procurar el bien común de todos los ciudadanos; segundo: acomodar las normas a cada caso en particular; tercero: su gobierno no se pierde en la dispersión, sino que es uno mismo el gobernante; cuarto: esta forma de gobierno procura dar unidad a todos los gobernados. Como nos dice Fray Luis, Cristo es el único que cumple con estas condiciones. Hay que recordar cómo, por arte de la metáfora, la naturaleza queda elevada a lo religioso. Aquí ocurre también. Al comparar esta forma de gobierno con la que se da entre los príncipes de la tierra, ocurre que ninguno de ellos la sigue y, por tanto, ni son perfectos ni son cristianos. Lo dice en muchas ocasiones. El discurso de Fray Cipriano de Huerga tenía que parecerle a Fray Luis una pura ilusión.

Ya en el tratado «De legibus» Fray Luis había antepuesto el espíritu a la letra de las leyes. En el comentario al Cantar de los Cantares hay una preocupación constante porque la ley se acomode a las condiciones de cada cual. El temor a la ley escrita que, como él mismo dice, es un señor ciego, pero todopoderoso, lo encontramos en todas sus obras. Esta justicia basada en la virtud natural del hombre proviene de la interna convicción de que lo natural y primario es perfecto. Después de lo que hemos estudiado, estas ideas nos resultan familiares. La razón que da en el «De legibus» es que, al principio, los hombres fundamentaron su convivencia sobre instituciones perfectas $\mathrm{y}$, sin embargo, no necesitaron de leyes escritas. Pero en el mismo tratado tendrá que admitir que, dado el estado de la condición humana, son necesarios tanto un juez perfecto como unas leyes que le ayuden ${ }^{23}$. Lo que es interesante destacar es que la convicción básica que subyace a estas ideas utópicas sobre el gobierno y la justicia es la de que el hombre es originalmente bueno, y que sólo la sociedad le hace perverso. Entonces es cuando se necesita la ley. De aquí la insistencia en proclamar el estilo pastoril como el más elevado.

En el «De legibus» Fray Luis sigue las teorías jurídicas, valientes y avan-

22. Op. cit. 446. Pastor.

23. «Dubitatur hic utra res esset utilior rei publicae gobernari ab optimo principe sine aliqua legum positione vel potius a legibus optimis sine principe... Et videtur quod esset utilius gobernari optimo principe sine aliqua lege scripta. Probatur quia respublicae a principio mundi fuerunt optimae institutae, et tunc nullae erant leges scriptae, ergo melius reguntur respublicae per optimos magistratos quam per leges». «De legibus», Madrid 1963, pág. 76. 
zadas, de los más prestigiosos juristas del Siglo de Oro. Pero cuando deja la pluma libre, como ocurre en las obras que no están atadas por el método escolástico, afloran sus sentimientos, a la par que sus ideas, y se organiza la defensa del espíritu frente a la letra. Erasmo la había proclamado ya bien alto. Había que volver al interior, a la realidad auténtica de las cosas. En la actitud de búsqueda de la auténtico se encuentra Fray Luis muy cerca del pensador de Rotterdam. Así, respecto a las ceremonias exteriores no las ataca, pero avisa que no está en ellas el verdadero caudal cristiano, y termina: «Así que, según que decía, el condenar la ceremonia es error; y el poner en ella la proa y popa de la justicia es engaño" ${ }^{24}$. La ley viva, que se acomoda a cada caso y quiere siempre lo bueno en cada momento, es la ley perfecta ${ }^{25}$. Pero esta ley y este gobierno, que se dan en Cristo y en la vida pastoril, no se dan entre los gobernantes de la tierra.

La tercera condición del gobierno al estilo pastoril incide en el sentido unitario que ha de tener la justicia. La dispersión del ejercicio del gobierno trae las diferencias de tratamiento. En el mundo ocurre que nunca gobierna uno solo «porque de ordinario viven en uno muchos, sus pasiones, sus afectos, sus intereses, que manda cada uno por su parte» ${ }^{26}$. Así pues, en esta utopía del gobierno, que Fray Luis añora, lo que se propone es el gobierno del mejor, tal como fue en su origen primero. En él estarán ausentes las pasiones que han apartado al hombre de su recto camino. El paradigma perfecto es la vida sosegada, inocente, sencilla y natural de la vida del campo. Toda utopía supone una evasión, una huida de la realidad inmediata. Ya es viejo este soñar de los españoles más destacados. Ello viene a confirmar la escisión que se da en el espíritu del escritor: este vivir desviviéndose cada día. Nostalgia continua de una realidad mejor. Américo Castro ha dado la pauta para interpretar el hecho de que los más notorios escritores del género pastoril en España fueran cristianos nuevos, como la huida del hebreo a un mundo más amable. Nadie como Fray Luis desarrolló tan amplia y agudamente esta contraposición entre el gobierno pastoril, que es algo ideal, y el que se daba en la realidad de su tiempo. Y que en todo ello hay una voluntad de expresar ideas bajo el velo de la creación literaria nos lo demuestra la acusación del Dr. Álvaro Picario de Palacio a propósito de un párrafọ que viene a incidir y aclarar la cuarta condición que el escritor encuentra en el gobierno pastoril. Ya hemos anotado que el hecho ocurrió en 1609, muerto Fray Luis. El pasaje, que ya había sido insinuado por algunos como incontrovertible, lo precisa Albert A. Sicroff en un libro sobre las controversias de los Estatutos de pureza de sangre en España ${ }^{27}$. Para entenderlo bien hay que recordar lo dicho sobre la igualdad de la so-

\footnotetext{
24. Op. cit. 754-755. Jesús.

25. Op. cit. 454. Pastor.

26. Op. cit. 455. Pastor.

27. Albert A. Sicroff, «Les controverses des statutes de pureté de sàng en Espagne du $X V^{e}$ au XVII ${ }^{e}$ siecle». Paris 1960.
} 
ciedad pastoril y la cuarta condición de este gobierno natural, que consiste en el sentido unificador que proyecta sobre personas y cosas. Las diferencias de sangre, raza o religión traerían la dispersión y el ataque a la igualdad básica de todos los hombres. Es ejemplo el reino de Cristo, tal como lo intuye el poeta en la sin par poesía «Morada del cielo». Es Sabino quien habla de este reino perfecto:

«Nobleza es - dijo - grande de reino aquesta, Juliano, que nos va haciendo Marcelo, adonde ningún vasallo es ni vil en linaje, ni afrentado por condición, ni menos bien nacidos el uno que el otro. Y paréceme a mí que esto es ser Rey propia y honradamente, no tener vasallos viles y afrentados» ${ }^{28}$.

Parece indudable que Fray Luis está aplicando las condiciones del gobierno al estilo pastoril a la situación de los hebreos y cristianos nuevos pues, en punto a ser afrentados por su linaje, éstos eran los más destacados, y casi los únicos, en España. El cristiano viejo de la última aldea española no se sentiría afrentado, por pobre que fuese. Estas líneas matizan toda la creación y significación de lo pastoril en nuestro poeta desde un trasfondo hebraico que, sin duda, estaba bien presente en él. Parece hacerse patente la sugerencia defendida anteriormente de que la ficción pastoril le sirve al escritor para lanzar muchas ideas peligrosas y equívocas bajo la forma literaria. Y hasta tal punto es sutil que no se comprende cómo tardaron tantos años en descubrirlo los sagaces informadores de la Inquisición. Es todo el problema de la honra lo que se debate aquí. Si en el Cantar de los Cantares eran honrados por igual el rey Salomón y su esposa pagana, aquí, en el reino en que vive nuestro poeta, las cosas son muy diferentes. Lo que abría el abismo entre las clases sociales del siglo XVI en España no era la riqueza, sino las diferencias de casta. Por eso Lope de Vega y Calderón podían equiparar al noble y al plebeyo. Lo que marcaba la diferencia y la desigualdad en aquella sociedad era el estar enfrentado o no por causa del linaje, es decir, la condición de cristiano viejo o nuevo. Fray Luis admite la diferencia de riquezas, y sólo atacará al señor por no pagar el jornal debido a sus asalariados. Es claro que cuando el poeta habla de igualdad se trata de una igualdad de linaje, casta y estimación. Aparece la angustia del descendiente converso. En definitiva, la creación pastoril es en Fray Luis la huida a un mundo ideal donde la honra sea también posible para la casta de los hebreos. Aquí aflora su melancolía infinita y su escisión entre el dolor y la impotencia ante la injusticia.

En el mismo pasaje que comentamos queda claro que no se piensa en una afrenta actual, sino en el hecho incomprensible de que vaya pasando de una generación a otra. Y aquí, categóricamente, hay un ataque contra la institución que permite este estado de cosas. Nos permitimos una larga cita para aclarar estas ideas:

«En esta vida, Sabino - respondió Juliano-, los reyes de ella para el castigo

28. Op. cit. 561. Rey. 
de la culpa están como forzados a poner nota y afrenta en àquellos a quien gobiernan. Como en la orden de la salud y en el cuerpo conviene a las veces maltratar una parte para que las demás no se pierdan. Y así, cuando esto, no son dignos de reprensión nuestros príncipes» ${ }^{29}$.

Fray Luis parece admitir el castigo por una culpa religiosa. Lo que le duele es la afrenta del pueblo hebreo en eterno cautiverio y «estado vilísimo entre sus enemigos, hechos como un ejemplo común de la ira de Dios» ${ }^{30}$, prolongado hasta los cristianos nuevos, sus descendientes. Fray Luis ataca a aquellos gobernantes que procuran que la afrenta se prolongue de generación en generación:

«-No los reprendo yo ahora - dijo Sabino-, sino duélome de su condición, que por esa necesidad que, Juliano, decís, vienen a ser forzosamente senores de vasallos ruines y viles. Y débeseles tanto más lástima cuanto fuere más precisa la necesidad. Pero si algunos príncipes que lo procuran y que les parece que son señores, cuando hallan mejor orden no sólo para afrentar a los suyos, sino también para que vaya cundiendo por muchas generaciones su afrenta, y que nunca se acabe, de éstos, Juliano, ¿qué me diréis? - ¿Qué? -respondió Juliano-. Que ninguna cosa son menos que reyes. Lo uno, porque al fin donde se endereza su oficio es hacer a sus vasallos bienventurados; con lo cual se encuentra por maravillosa manera el hacerlos apocados y viles. Y lo otro, porque, cuando no quieran mirar por ellos, así mismos se hacen daño y se apocan. Porque, si son cabezas, ¿qué honra es ser cabeza de un cuerpo disforme y vil? Y, si son pastores, ¿qué les vale un ganado roñoso? Bien dijo el poeta trágico: Mandar entre lo ilustre es cosa bella» ${ }^{31}$.

Es interesante apuntar cómo Fray Luis sigue comparando a los gobernantes con pastores. Vemos de nuevo que la idea de reino-rebaño y de gobernantes-pastor están unidas en la mente del escritor. Así que la acusación de Álvaro Picario contra estos párrafos muy bien podría haberla hecho contra todo el trasfondo que tiene lo pastoril en Fray Luis. Es curioso notar también cómo el poeta pone estas acusaciones en boca de Sabino y Juliano, y no en la de Marcelo, que se supone era él mismo. Según Álvaro Picario, estas ideas van contra la Inquisición, que castiga la falta trasmitiendo el deshonor de una generación a otra, y va contra las leyes del rey que excluyen a estos individuos de las Ordenes Militares. Picario denuncia este pasaje también porque parece condenar la exclusión de los conversos de las iglesias y de los colegios, y porque parece predicar una igualdad entre los cristianos viejos y nuevos.

Fray Luis contrapone la situación actual de los hebreos en las tierras de España al perfecto gobierno, que es el de Cristo, y que se realiza al modo pas-

29. Op. cit. 561. Rey.

30. Op. cit. 515. Continúa: «A mí, verdaderamente, cuando lo pienso, el corazón se me enternece de dolor». Ded. L. II.

31. Op. cit. 561-562. Rey.

32. Albert A. Sicroff, Op. cit. pág. 264-265. 
toril. Continúa diciendo Fray Luis que los gobernantes manchan su honra cuando buscan manchar la de los gobernados, al mismo tiempo que ponen en peligro la armonía y la paz. No es posible que exista la paz donde unos viven con mucha honra y otros con poca, o con señalada afrenta. Una sociedad así está sujeta a morir, porque «la propia lástima e injuria de cada uno encerrada en su pecho, y que vive en él, los despierta y los hace velar siempre a la ocasión y a la venganza» ${ }^{33}$. La armonía y la unidad son las categorías fundamentales de la estética luisiana respecto al cosmos y a los hombres entre sí.

En definitiva, la vida de la sociedad y su gobierno en nada se parecen a la encantadora utopía pastoril que ha creado nuestro poeta. Pensamos que la creó precisamente para exponer ese doloroso e injusto contraste entre el mando y la honra de unos y la humillación y afrenta de otros. Lo pastoril se nos presenta aquí enriquecido al máximo al ser propuesto como el medio de la comunicación de un gran mensaje: el del amor, la paz y la justicia entre todos los hombres sin diferencias preestablecidas de ningún tipo.

\section{Lo rústico y lo social}

Lo pastoril tiene en la obra luisiana una amplitud y trascendencia más hondas que los comentarios sobre la vida del campo y la labranza. Lo pastoril es un estilo de vida y una superación de las escisiones de la sociedad por medio de la creación artística. La vida del campo, como lugar en que viven y trabajan hombres reales, tiene un sentido más ético. Las ideas veladas, por peligrosas y comprometidas, de lo pastoril, se hacen patentes en la oposición campociudad. El mensaje que lanza el poeta a través de este contraste es de tipo social. No llega al alcance que tiene la significación de la literatura de pastores. Puede expresarse con claridad. Por ello, aquí no hay ficción, sino una realidad meridiana. Esta forma de vida es también inocente y pura, pero está menos idealizada. Al fin y al cabo, era el modo de vivir de la mayoría. Sigue la tradición iniciada en tiempo de los Reyes Católicos, y cuyo máximo exponente es Antonio de Guevara con su «Menosprecio de Corte y alabanza de aldea», que se publica en 1539. Isaza Calderón ha estudiado el comienzo de esta forma de ver la aldea como el lugar de toda virtud frente a la Corte, donde el vicio tiene su asiento propio. En lo pastoril el escritor se encuentra inmerso en su creación, ya que forma parte de su existencia y anhelos personales. En el tema de la alabanza de aldea el escritor puede actuar más objetivamente, como un moralista que estudia y ve las cosas desde la distancia. Así ocurre con la insinceridad manifiesta del Obispo en Corte. En Fray Luis, esta actitud crítica ante el contraste que se establece entre el campo y la ciudad, responde a unas ideas estéticas y a una sinceridad personal absoluta. El principio estético de que parte es el ya conocido de la superioridad de la naturaleza sobre toda cre-

33. Op. cit. 562. Rey. 
ación artificial. Esta superioridad se matiza de un valor moral al considerar la naturaleza y el campo como lo más puro venido de las manos de Dios. El amor ciego de Fray Luis al campo y a sus gentes nos resulta algo familiar: responde a una necesidad íntima de sosiego.

Si antes estudiábamos la comparación que hace el poeta entre el gobierno de los príncipes y el pastoril de Cristo, lo que vemos ahora es una comparación entre las diversas clases del país desde la perspectiva de la vida del campo. Contrapone, de una manera especial, la vida de los nobles y poderosos económicamente con la de los humildes labradores y colonos que labran las tierras ajenas. En lo pastoril se proponía un ejemplo a seguir; aquí hay un ataque directo a los poderosos y adinerados. Veremos sobre qué bases. Junto a la inmensa ternura por los humildes, nos parece observar una cierta enemiga contra el poderoso que puede comprarlo todo por dinero. No sabemos, a veces, si la alabanza de la vida del campo es una idea sustantiva en sí, o es una exaltación para contrastarla con la vida de los nobles y adinerados de la ciudad. Y que hay una gran carga moral en todo ello nos lo muestra el hecho de que Fray Luis no ataca a todas las clases poderosas por igual. Frente a la virtud bíblica del trabajo del labrador, el poeta ve la pereza como el vicio más destacado de la clase de los señores y renteros.

De las tres formas de vida del hombre, la labranza, el comercio y las rentas, la primera es la más perfecta. Las otras dos en tanto lo son en cuanto se allegan a ella ${ }^{34}$. Observamos que no habla de la pastoril, bien porque la incluya dentro de la labranza, o porque ello signifique un mundo aparte de creación literaria y vehículo de ideas. Cuando habla de labranza, Fray Luis entiende, manifiestamente el cultivo del campo. El amor y la armonía del cosmos, que invitaba al hombre a un sentimiento de fascinación y comunicación, se convierte ahora en una valoración ética por la que la tierra, que es fiel en hacer brotar las plantas y dar sustento al hombre, nos invita a una vida de verdad y buenas costumbres:

«Mas, al revés, la vida del campo y el labrar uno sus heredades, es una como escuela de inocencia y verdad; porque cada uno aprende de aquello con quien negocia y conversa. Y como la tierra en lo que se le encomienda es fiel, y en el no mudarse es estable, y clara y abierta en brotar afuera y sacar a luz sus riquezas, y, para bien hacer, liberal y abastecida, así parece que engendra e imprime en los pechos de los que la labran una bondad particular, y una manera de condición sencilla, $y$ un trato verdadero y fiel y llenos de entereza y de buenas y antiguas costumbres, cual se halla con dificultad en las demás suertes de hombres" ${ }^{35}$.

La definición de la vida de labranza como una escuela de inocencia y verdad es del todo semejante a la de la vida pastoril que es una «escuela de amor

34. Op. cit. 262. La Perfecta Casada, 4.

35. Op. cit. 253-254. La Perfecta Casada, 2. 
puro y verdadero». En ambos casos se siente a la naturaleza como colaboradora en la formación de un hombre mejor. La vida del campo y el vivir uno de su patrimonio es inocente y sosegado, lejos de la vida andariega del comerciante que lucha en los caminos y mesones. La vida de labranza es, en una palabra, un modelo de vivir honesto.

Desde esta perspectiva Fray Luis ataca el abuso de los señores dueños de las tierras, y rompe lanzas a favor de los colonos y asalariados. Tiene una idea organicista de la sociedad. Al tratar de lo pastoril, ya vimos cómo define a los gobernantes como cabezas de los miembros que son gobernados. La idea debía fundarse en la metáfora que concibe a los fieles y a la Iglesia como un cuerpo. La semejanza se continúa a la sociedad heril. A la metáfora procedente del Cuerpo místico de la Iglesia, que adquiere fortuna en la Contrarreforma, hay que añadir el sentido de la armonía que aparece en todas las concepciones luisianas. Las únicas diferencias reales que admite Fray Luis entre los hombres son de carácter funcional. El cuerpo de la sociedad sufre lo mismo con una cabeza endeble que con unos miembros viles y afrentados. Por ello, al honrar los señores a los criados, a sí mismos se honran, como ya hemos visto. Deja bien clara la igualdad de unos y otros ante la ley, por serlo ante la naturaleza y haber sido hechos por un mismo artífice, en un mismo lugar y de la misma materia ${ }^{36}$. Aunque admite la diferencia de bienes económicos, no parece comprenderla bien. Hemos de tener en cuenta que, entonces, estas diferencias eran producidas, en gran manera, por las herencias y el linaje. Pero todo lo que implicara volver al pasado, era una fuente de amargura para nuestro poeta, que recordaba las insultantes diferencias que se habían originado entre los descendientes de los hebreos y los cristianos nuevos. Fray Luis no puede admitir noblezas de sangre y, por ello, no comprende bien las riquezas heredadas. A este respecto téngase en cuenta su idea de que los reyes no lo son por naturaleza, sino porque fueron elegidos y detentan el poder delegado del pueblo ${ }^{37}$. No hay carismas que diferencien unos hombres de otros. En cualquier caso, la opinión de Fray Luis sobre el poder público no resulta halagüeña ${ }^{38}$.

La simpatía por la labranza y el sufrimiento del labrador es permanente.

36. Op. cit. 1.141. Job, 31,15.

37. «Item sic: reges, si vere reges sunt, omnem suam potestatem et omne ius dominandi habent a natura ut imperent aliis, sed consensu populi vel expresso vel tacito factum est ut unus coeteris praesset...» «De legibus», pág. 29.

38. «Porque, a la verdad, todo este poder temporal y terreno que manda en el mundo, tiene más de estruendo que de substancia, y pásase como el aire volando, y nace de pequeños y ocultos principios. Y como las bestias carecen de razón y se gobiernan por fiereza y por crueldad, así lo que ha levantado y levantan estos imperios de la tierra, es lo bestial que hay en los hombres: la ambición fiera, y la codicia desordenada del mando, y la venganza sangrienta, y el coraje y la braveza y la cólera y lo demás que, como esto, es fiero y bruto en nosotros, y así finalmente perecen». Op. cit. 571-572. Rey de Dios. 
En una párrafo magnífico expresa los trabajos del colono y el contraste con la vida muelle e injusta del dueño de las tierras:

«Porque sin duda es mal grandísimo al pobre labrador que con el sudor suyo y de su familia ha lacerado todo un año, volviendo y revolviendo la tierra, pasando malos días y no descansando las noches, madrugando y ayunando, al calor y al hielo, en la cultura del campo, y lo que es más, confiando en las aradas ese poco trigo en que estaba su sustento y su vida; el señor del suelo donde sembró, ocioso y descansado y durmiendo, al fin de su trabajo, despojarle de todo el fructo dél y comer el ocioso y vicioso tantos sudores ajenos, y alegrarse él con lo que el miserable llora y sospira» ${ }^{39}$.

La sintaxis quebrada del párrafo muestra la urgencia y la ira de nuestro escritor ante la injusticia que sufren los trabajadores del campo. Como él mismo dice, fruto de estas injusticias es la esterilidad de la tierra, o porque así lo ordena Dios, o porque los labradores, maltratados, abandonan su cultivo.

Al contraste de la vida del campo, que es inocencia y verdad, con la de la ciudad, que es mentira, se une el de la vida muelle de los señores frente a los desgraciados colonos. Es el hombre quien por el pecado, ha traído el mal y la injusticia al mundo. Ello se concreta en la sociedad urbana que tiene sojuzgada a la noble y aunténtica del campo. La vuelta a la naturaleza adquiere así una dimensión social que viene a enriquecer las perspectivas múltiples que tiene el tema. Vemos que esa vuelta matiza y ordena el ser completo del hombre en su vivir en sí mismos y en sus relaciones con Dios y con los demás hombres. La realización del hombre en su creación sobre la base del descubrimiento de la naturaleza es la más rica dentro del punto de vista ético. Pero se completa con la visión de lo divino y la comprensión de un orden social más perfecto. La contradicción entre la verdad de la vida del campo y la miseria de sus gentes con la mentira de la sociedad urbana y la abundancia de los que en ella viven, es fuente de un profundo dolor para el escritor. Viene a aumentar la melancolía que produce lo irremediable. El hombre ha trastocado el orden de los valores. He aquí un elemento más para la situación de angustia que se plantea en los mejores espíritus del Siglo de Oro español. No es posible la serenidad en un mundo presidido por unos valores que están muy lejos de ser los auténticos, precisamente porque se han alejado del orden natural que Dios estableció. Lo que importa en el motivo luisiano del campo, aun tratándose de algo fáctico y existencial, es el fondo del problema. Porque Fray Luis sabe que el hombre es sociable por naturaleza y necesita de los demás; pero esto ha de ser en armonía y ayuda mutua, como acontece entre los elementos de la naturaleza que colaboran para dar los frutos de la tierra, y en el cosmos, donde los planetas se mantiene en sus propias órbitas ${ }^{40}$.

39. Op. cit. 1.148. Job, 31,39 .

40. «Ad huius rei explicationem advertendum est primo loco quod homo natura sua est animal sociabile et inclinatum a natura ad defendendam vitam simul cum aliis et cum aliorum societate, quae dicitur vita politica seu civilis» «De legibus», pág. 49. 
Por oposición a la vida del campo y su laboriosidad y sencillez, Fray Luis se ha fijado en dos vicios, principalmente: la presunción y la pereza de los nobles y señores. El escritor da en el blanco con maestría. Evoca el recuerdo de los días felices en que trabajo y nobleza se hallaban hermanados. Los romanos dejaban el arado para desempeñar las funciones de la República. A él volvían cuando cesaban en el gobierno. Ý ellos eran los señores del mundo.

La tercera forma de vida que distingue Fray Luis es la de aquellos «que comen de sus tierras, pero labradas con el sudor de otros, y tenga por nombre vida descansada» ${ }^{41}$. No va aquí contra el sistema establecido, puesto que admite los tres tipos de vida como igualmente justos. Lo que no puede tolerar es la pereza de los señores que se levantan tarde, no hacen nada y, al final del año, recogen la riqueza que otros han hecho para ellos. La pereza es el vicio origen de todos los males. Porque el trabajo es la sal de la vida, lo que conserva las cosas sin corromperse:

«Muchas cosas están escritas por muchos el loor del trabajo, y todo es poco para el bien que hay en él; porque es la sal que preserva de la corrupción a nuestra vida y a nuestra alma» ${ }^{42}$.

Es curioso cómo Fray Luis aconseja constantemente el madrugar. Recordamos cómo en Los Nombres de Cristo los personajes se levantan muy temprano. En La Perfecta casada dedica casi un capítulo entero a este tema. Nos dice que la naturaleza, que nos envía la luz, quiere que nos levantemos pronto. Por la mañana el mundo entero despierta, una nueva luz abre los ojos de los seres vivientes. En este punto la diatriba luisiana contra los señores y los nobles es una de las más fuertes de toda la obra. El poeta pinta con vivos colores la llegada de la mañana que lo anima todo. Los señores, que en todo lo demás son esclavos del placer, se pierden la maravilla de ver la luz con una alegría nueva, y el colorear de las nubes, y el descubrirse la aurora coronada de rosas, y el canto de las aves, y el olor de las flores y las yerbas. Los hombres cuerdos no han de perder esta fiesta que nos ofrece la naturaleza cada mañana. Hasta el frescor del aire cría salud, lava las tristezas del corazón y lo despierta a pensamientos divinos antes de entrar en los negocios del día. Esta es la madrugada del hombre del campo. La del adinerado es muy diferente. El contraste es fortísimo:

«Y no contradice a esto el uso de las personas que agora el mundo llama senores, cuyo principal cuidado es vivir para el descanso y regalo del cuerpo, las cuales guardan la cama hasta las doce del día. Antes esta verdad que se toca con las manos, condena aquel vicio, del cual ya por nuestros pecados 0 por sus pecados de ellos mismos hacen honra y estado...» ${ }^{43}$.

41. Op. cit. 262. La Perfecta Casada, 4.

42. Op. cit. 278. La Perfecta Casada, 8.

43. Op. cit. 273. La Perfecta Casada, 6. 
Continúa Fray Luis diciendo que él conoció a una persona que sabía calificar certeramente este vicio:

«Así que, cuando le decía alguno que era estado de los señores este dormir, solía responder que se erraba la letra, y por decir establo decían estado».

Es uno de los pasajes más sarcásticos de nuestro escritor. La pereza, la hipocresía y la necedad son vicios que fustigó continuamente.

No son estas diatribas algo objetivo y distanciado, como las del Obispo en Corte. Las palabras son demasiado duras como para hacer de ellas un simple ataque de una desviación ética. El escritor se halla implicado en todo ello. Hay que admitir que su enemiga contra los nobles y señores es muy grande. El concepto de la naturaleza como lugar de la vida más auténtica aparece elaborado hacia formas de convivencia humana. El contraste entre la vida del campo y la de la ciudad ofrece al escritor el camino para hondas consideraciones éticas. La moral de los hombres está referida a la naturaleza. Para ser perfectos lo único necesario es imitar esa vida. En ella vive Cristo. En La Perfecta casada repite la idea de que la tierra es engendradora de todo ${ }^{44}$. A ella hay que volver como al momento original de todo lo existente.

Esta concepción de la sociedad como un todo armónico tiene mucho que ver con las ideas erasmistas. Según Erasmo, la ley que está escrita en el fondo de los seres, se halla en consonancia con la ley divina. La creación entera, los astros, los animales que la pueblan, siguen la ley que Dios les impuso. Por ella se acercan a El. Sólo el hombre traiciona esta armonía. La tragedia es tanto mayor si consideramos que el hombre es el único ser capaz de elevarse hasta la noción de Dios ${ }^{45}$. En todo este volver a la naturaleza se encuentran hermanados los mejores espíritus del Renacimiento. Las implicaciones estéticas, éticas y trascendentes son muchas. Volver a la naturaleza es poner al hombre en consonancia consigo mismo y con Dios. Y como el hombre es sociable por naturaleza, habrá que armonizar también la sociedad en que vive. De aquí que el pensamiento social y político de Fray Luis esté determinado, en sus rasgos fundamentales, por el sentido de armonía que domina el mundo y el universo todo. Las actividades del hombre han de cooperar al bien de la comunidad y, mediante ello, a la armonía del cosmos ${ }^{46}$. El mismo Azorín, que en algunos aspectos no supo o no pretendió adentrarse en Fray Luis ha sabido ver muy bien esta vinculación de la naturaleza y lo político y lo social en la obra luisiana ${ }^{47}$.

44. Op. cit. 251. La Perfecta Casada, 2.

45. V.: M. BAtAillon, «Erasmo y España». México 1950, pág. 86.

46. FraY LuIS, «De legibus», págs. 22-27.

47. «En Fray Luis, poeta, autor de Los Nombres de Cristo, autor de La Perfecta Casada, traductor de Virgilio, domina el amor intenso a la naturaleza. Pero Luis ama la naturaleza como espectador (estéticamente) y como propugnador de una fórmula social que ha de resolver las diferencias y conflictos humanos (es decir, políticamente)», pág. 182). «Pero en el sentido del campo 
La interpretación política y de castas que el poeta hacía de la naturaleza en lo pastoril, se completa ahora con esta visión social. Mientras la primera concepción versaba sobre las grandes ideas de comunidad y gobierno, el contraste entre la vida del campo y la ciudad adquiere un tono más individualista y ético. Es el gran sistema de lo pastoril venido un poco a menos. En todo caso, aumenta las perspectivas del tema. La herida de la injusticia es ahora contra las gentes del campo. Y se trata de una existencia bien real. Hay una confusión en Fray Luis al intentar comprender cómo se da el dolor y el abuso entre aquellos hombres que hacen la vida más auténtica, la del campo. Es la misma preocupación que le llevó a pensar muchos años en la difícil justicia del Libro de Job.

\section{Actitudes estéticas}

Derivan estas actitudes de ver la naturaleza como lo más puro y genuino de la creación. No sólo se ha de volver al campo y a la naturaleza, sino a todo aquello que nos recuerde el pensamiento que hay en la base de ese retorno: el de la cercanía al origen y lo divino de lo natural. La lucha entre ese acercamiento a la realidad interior de las cosas a través de lo aparencial produce un sentimiento de melancolía que tiñe de tristeza nuestra visión de lo existente.

\section{A. La melancolía}

La melancolía está íntimamente relacionada con la comprensión luisiana de la naturaleza. Hay en la obra de Fray Luis algunas descripciones exactas y precisas de la tristeza melancólica indefinible que se cuelga de todas las manifestaciones de su creación.

La melancolía es una enfermedad o forma de actuar que está de moda en el Renacimiento. Las damas se muestran pálidas y tristes al exterior para significar un pensamiento profundo. Hay muchas interpretaciones del hecho de la melancolía. Puede deberse a una situación patológica, propia del artista, como pensaba Marsillo Ficino, o a una situación exterior por la que el artista, a la vista de los desastres de la fortuna, de la comparación entre lo ideal y lo real, del dolor, cae en la más profunda tristeza. Los renacentistas ponen la melancolía en relación con la astrología. El grabado de Durero «La Melancolía» es la mejor representación de esta tristeza: una mujer alada, rodeada de signos matemáticos y naturalistas, mirando hacia la palabra melancolía ${ }^{48}$. En

en Fray Luis, su pasión intensa por la naturaleza tiene relación íntima con su sociologia», (pág. 185).

Azorín, «Obras Completas». Madrid 1961, t. IV, «Los dos Luises y otros ensayos».

48. Recientemente, José Camón Aznar, en un artículo del diario A.B.C., ha interpretado este cuadro de una forma completamente distinta: la mujer no es tal, sino un ángel alado y representa la huida de la melancolía ante el dominio de la naturaleza por la razón. 
Fray Luis encontramos tanto el factor patológico como la visión triste del mundo exterior combinados para darnos una vaga nostalgia melancólica que vuela sobre toda su obra.

Vemos en Los Nombres de Cristo cómo Marcelo se pasa largas horas mirando a las estrellas durante la noche. Este refurgiarse en lo nocturno tiene relación con la melancolía. La noche es comunicación y sosiego pero, al mismo tiempo, simboliza la obscuridad intelectual. El poeta levanta sus ojos a las estrellas a la búsqueda de la intelección total. No es casualidad que la melancolía estuviera de moda en el Renacimiento y que fuera cultivada, de una manera especial, por los neoplatónicos. Ella nace de la impotencia de dominar la naturaleza a la luz de la idea platónica de que la realidad auténtica está en lo inteligible de las cosas. Es aquel sentimiento de fascinación que le hacía quedarse a Marcelo fascinado ante el paisaje de La Flecha y ante la vista de la noche estrellada de Salamanca. Aquí tenemos la clave de tanta ternura como hay en las páginas luisianas sobre la naturaleza. Cuando Sabino dice que la vista del campo enmudece a algunos y que ello debe ser cualidad de espíritus de pensamientos profundos, Marcelo le contesta, precisando:

«Bien entiendo por qué lo decís - respondió Marcelo-; y no es alteza de entendimiento, como dais a entender por lisonjearme o consolarme, sino cualidad de edad y humores diferentes; que nos predominan, y se despiertan con esta vista, en vos de sangre y en mí de melancolía» ${ }^{49}$.

Queda claro, primero, que la melancolía comportaba unaxforma inteligente de mirar las cosas exteriores y, segundo, que era producto de una condición patológica, pero que se despertaba al toque mágico de la naturaleza. En el caso de Los Nombres de Cristo es la vista de la huerta de La Flecha con los montes de Gredos al fondo y las luces del cielo estrellado por la noche. ¿En qué pensaría el poeta? En nada, quizás. La melancolía lo envuelve todo en una visión lánguidamente faústica, llena de gozo por lo que tenemos y de insatisfacción por aquello de que carecemos. Cuando el hombre se empeña en encontrar la realidad íntima de las cosas, tiene a su lado a la melancolía matizando de tristeza su camino. Por ello crece durante la noche, cuando los sentidos están adormecidos y la mente y el corazón se enfrentan con el enigma de lo existente. La tristeza del día se torna en terror y stieños funestos durante la noche. Lo sabía muy bien Fray Luis, que tantas noches pasó en vela, contemplando el cielo. Por eso supo entender el dolor de Job ${ }^{50}$.

A la melancolía de Fray Luis, que le hacía arder el corazón durante la noche, debemos algunas de las poesías más bellas de la literatura universal. Los conflictos, las luchas le producían también aquella tristeza ${ }^{51}$. La melan-

49. Op. cit. 393. Intr. L, I. Nombres de Cristo.

50. Op. cit. 909. Job, 7,13.

51. En la petición que hace Fray Luis, estando preso en las cárceles de la Inquisición, en Valladolid, el día 3 de marzo de 1572, poco después de ser encarcelado, escribe estas patéticas 
colía es en él el amor y la pena que despierta en él la comparación entre el mundo de verdad de las estrellas y el del sueño y el olvido en que se halla el mundo en la «Noche serena». La melancolía, teñida de nostalgia, es el efecto que produce en el alma la contemplación y el pensamiento profundo sobre los elementos de la naturaleza. La melancolía de Fray Luis no es un tópico estético. Está dentro de su existencia; está en el desencanto que produce la lucha del entendimiento frente al mundo y frente a todo orden doloroso. M. Bataillon se pregunta si la melancolía renacentista no tendrá mucho de hebrea. Puede ser. Lo cierto es que se encuentra la más honda tristeza precisamente en aquellas páginas en que el poeta de Salamanca comenta el gobierno de los hombres según el pastoril modelo de Cristo, y cuando ataca a los señores que roban el sudor del pobre labrador. En el género pastoril hay siempre una secreta melancolía que procede del origen mismo de la creación literaria, porque ello significa la huida a un mundo mejor. Pero ninguna huida se produce sin dejar algo de nosotros mismos en el camino. De aquí que haya en lo pastoril la presencia, por contraste de su ausencia, de un no sé qué de mundos lejanos e ideales. En primer lugar, es imprescindible en lo pastoril el juego de amor entre el amante y la ausencia del amado o amada. Desde el comienzo de la Exposición del Cantar de los Cantares propone Fray Luis la dialéctica del amor en términos de ausencia y melancolía. Describe magistralmente sus consecuencias ${ }^{52}$. La decepción ante el desconocimiento de la naturaleza se torna en la tristeza y desvarío por la ausencia del amado. Con ello se completan las dos fuentes-exteriores de la melancolía: la ausencia de lo que puede llenar la facultad intelectiva y la ausencia de lo que puede llenar la del corazón.

Aparece también la melancolía luisiana en relación con la naturaleza en el sentimiento indefinible de temporalidad que encontramos en sus obras, especialmente sus poesías. Es permanente en él la idea del paso del tiempo como algo inexorable. El tiempo se vincula al paso de las estaciones del año y las ruinas y destrucción que causa en las cosas de la naturaleza. Sentimiento completamente barroco que pone una gota de tristeza en todo. De ahí que la alegría del poeta nunca sea total. Está siempre detrás el dolor de lo cambiante y la dolorida actitud ante unos hechos exteriores que se nos imponen. Es el tiempo lo que nos corta el camino hacia la intelección total. Y en esta impo-

\footnotetext{
líneas: «Y suplico a sus mercedes sean servidos dar licencia para que se le diga al dicho Padre Prior que avise a Ana de Espinosa, monja del monasterio de Madrigal, que envie una caja de unos polvos que ella solía hacer para mis melancolías y pasiones de corazon, que ella sola los sabe hacer, y nunca tuve de ellos más necesidad que agora...» SALVÁ Y BARANDA, «Documentos inéditos para la Historia de España». Madrid 1847, t. X, pág. 179).

52. «Pues entenderemos que en este primer capitulo comienza a hablar la esposa; que habemos de fingir que tenía a su amado ausente, y estaba de ello tan penada, que la congoja y el deseo la traía muchas veces a desfallecer y desmayarse... De lo cual dan muestra la amarillez del rostro y la flaqueza del cuerpo y desmayos del corazón, que proceden de este enajenamiento del alma». Op. cit. 69. Cantar, 1,1.
} 
tencia temporal de aprehender el mundo se halla el más sutil sentimiento de melancolía.

\section{B. La exaltación de los valores espontáneos}

La vuelta a la naturaleza durante el Renacimiento se proyecta sobre todos los acontecimientos de la vida que implican un retorno a lo primitivo y natural del hombre. A la luz de esta idea hay que interpretar muchos aspectos de la estética renacentista. A la tradición platónica se une un cansancio de siglos en los que el hombre se ha visto desintegrado entre sus apetencias más hondas y el sistema que se le imponía. En el siglo XV entran en crisis las ideas que han alimentado los espíritus durante la Edad Media. La realidad había cortado ideales y había segado muchos sueños. El ideal de vida caballeresco, con sus apetencias imposibles, entra ya en la novela, que es lo mismo que empezar a morir. Cuando la vida real entra en la novela es que otra vida nueva está haciendo acto de presencia. Como indica Huizinga, «en aquella época el arte aún está absorbido por la vida. La vida está apresada en rígidas formas. Está encauzada por los sacramentos, las fiestas del año y las horas del día, y es medida por ellos. Los trabajos y las alegrías de la vida, todo tiene su forma fija» ${ }^{53}$. La vida y el arte se regían por unos modos fijos. El hombre se encontraba encadenado por el símbolo y el artificio. La expresión de la naturaleza es completamente convencional. El hombre tenía necesidad de espontaneidad; tenía que encontrarse a sí mismo. De la crisis de los valores medievales que se produce en el siglo XV y de la vuelta de los humanistas a los modelos clásicos, nace una nueva forma de entender el arte y la vida. Junto a la base filosófica neoplatónica que diviniza la naturaleza, se acentúa el contraste entre las bellezas naturales y las creaciones del hombre. Adquiere categoría de arte el fondo poético de los pueblos. En España se traduce en la magnífica floración de los romances. Todo lo del pueblo es estimado. Tanto más cuanto que antes había sido menospreciado por los hombres mejor cualificados. Al imitar los nobles la vida natural en el juego de lo pastoril, dieron el espaldarazo a todo estilo de vida que supusiese un volver a lo natural. La crisis de las ideas medievales tiene un reflejo doloroso en la religión. La Iglesia se encontraba anquilosada en la norma y la letra. Al venir la reforma, Lutero predica una vuelta a las fuentes, a la Biblia. Desde la ortodoxia Erasmo defiende el espíritu frente a la letra, Fray Luis se halla también dentro de esta corriente de vuelta a las fuentes. Sabemos que, junto a la envidia y la mentira, le costó cinco años de cárcel. La vuelta a la naturaleza implica la vuelta a los valores espontáneos, a las cosas pequeñas. Para ser perfecto, el hombre tenía que volver a todo aquello que le mostrase tal cual era. A lá luz de estas ideas es como.hay que interpretar la defensa que hace Fray Luis de la lengua vulgar, su sentido de la

53. HuIZINGA: «El otoño de la Edad Media». Madrid 1945, pág. 361. 
belleza y el arte, el gusto por los proverbios y refranes, y su encendido cariño por los niños.

\section{a. Los niños}

El poeta se ha fijado muchísimas veces en la espontaneidad de los niños. Hay en él una secreta ternura que contrasta con la agitación de su vida. Hemos encontrado en sus obras más de una decena de párrafos y observaciones bellísimas sobre los niños y el cuidado de sus madres. Espigaremos algunos detalles.

Fray Luis ha visto que las muchachas se comen a besos a los niños en las calles ${ }^{54}$, y concibe el regazo de las madres como la posada a la que han de acudir para estar seguros ${ }^{55}$. Él ha puesto su atención en un juego de niños que se parece a lo que hace el cosmético con las muchachas que, diciendo que las pinta, las burla y entizna ${ }^{56}$. A los amantes, en sus idas y venidas les ocurre lo que a los niños cuando juegan al tras ${ }^{57}$. El poeta describe algo que todos hemos visto alguna vez:

«... cuando una madre ha estado ausente de su niño, y en viniendo luego pide por él y lo llama y lo abraza, mostrándole aquella terneza de regalo que le tiene, lo primero que él hace es quejarse de quien le ha ofendido en su ausencia, y con unos graciosos pucheritos relata, como puede, su injuria y pide a la madre que le vengue» ${ }^{58}$.

Al leer el nombre «Brazo de Dios» nos sonreímos al ver cómo en tiempos de Fray Luis, igual que ahora, era necesario animar a los pequeños con algún dulce para que aprendieran la lección. Así, Dios hace con los hombres «como el ayo al muchacho pequeño le induce con golosinas a que aprenda el saber» ${ }^{59}$. El poeta ha visto a los niños jugando cuando van a tomar el pecho de la madre. La observación es atinadísima ${ }^{60}$. La vista de un niño poniéndose de puntillas sobre los pies de la madre, es de una ternura y un encanto sin par:

"¿No habéis visto algunas madres, Sabino, que teniendo con sus manos las dos de sus hijos, hacen que sobre sus pies de ellas pongan ellos sus pies, y así los van allegando a sí y los abrazan y son juntamente su duelo y guía?» ${ }^{61}$.

54. Op. cit. 184. Cantar, 8,2.,

55. Op. cit. 850. Job, 3,11.

56. Op. cit. 291. La Perfecta Casada, 11.

57. Op. cit. 97. Jugar al tras: «Tras, tras», llaman los muchachos al que es penúltimo en grado de alguno de sus juegos, contando entre cuatro». Diccionario de Autoridades.

58. Op. cit. 101. Cantar, 2,15 .

59. Op. cit. 530. Brazo.

60. Op. cit. «Porque ¿qué trabajos no paga el niño a la madre cuando le tiene en el regazo, desnudo; cuando él juega con la teta; cuando la hiere con la manecilla; cuando la mira con risa; cuando gorjea? Pues cụando se le anuda al cuello y la besa, paréceme que aún la deja obligada». (Op. cit. 332. La Perfecta Casada, 17).

61. Op. cit. 436-437. Camino. 
No es necesario comentario alguno a estos textos. La riqueza de la sensibilidad de Fray Luis es muy grande. Es la maravilla de lo natural y lo espontáneo. Y no sólo esto. En el año 1569 nace doña Tomasina, hija de los marqueses de Alcañices y nieta de san Francisco de Borja. Fray Luis le dedica una poesía a esta niña. Los versos serán un tanto afectados y obligados, pero llenos de imaginación.y galanura. Al fin y al cabo, en poetas de la talla de Fray Luis la inspiración discurre con libertad. Nosotros comprendemos ahora la ternura que le llevaría a escribir esta poesía. Los años juveniles del poeta, llenos de saber clásico, miden su emoción. Pero ahí queda esta oda como prueba y culminación de su encanto por los niños. Es la titulada «En el nacimiento de doña Tomasina, hija del Marqués de Alcañices, don Álv́aro de Borja y de doña Elvira Enríquez». Se desarrolla dentro de una inspiración platónica con reminiscencias del «Somnium Scipionis». Canta la hermosura y cualidades de la futura mujer. La poesía termina con estas dos liras:

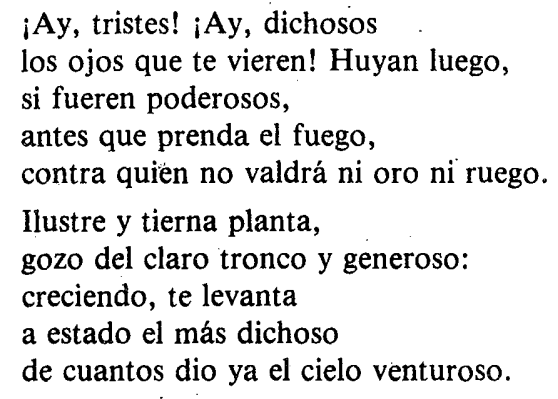

Nada hay más natural que el encanto de los niños. Una vuelta al hombre que fue niño, es lo que propone Fray Luis. Porque en ese momento es cuando se encuentran más hermanados que nunca la naturaleza y el hombre. En ese punto todo es verdad e inocencia original y divina.

\section{b. La lengua vulgar y la sabiduría popular}

Dentro de este contexto de exaltación de los valores espontáneos hemos de situar la defensa de la lengua vulgar, ya clásica, que hace Fray Luis. La escribe en la dedicatoria del libro $3 .^{\circ}$ de Los Nombres de Cristo. Se entusiasma también con los dichos lapidarios y llenos de sentido del pueblo.

El Bembo en Italia, Du Bellai en Francia y Nebrija y los hermanos Valdés en Espana fueron los iniciadores de la defensa de la lengua romance. En Alemania, Lutero, al traducir la Biblia al alemán no sólo levantó un monumento a la lengua vulgar, sino que consiguió hacerse con muchos adeptos por ese medio. El darse a entender de las gentes sencillas es una idea que está en la base de la defensa luisiana del cảstellano. El mismo ambiente humanístico que proclamaba una vuelta a las lenguas clásicas, favoreció el encuentro con la lengua romance. Con sagacidad, supo expresar Fray Luis las razones de este 
encuentro: el latín o el griego eran la lengua vulgar de aquellos que la hablaban. Por otra parte, la lengua vulgar romance había nacido de las fuerzas primitivas del pueblo, y esto le daba un atractivo singular. Es la lengua que aprenden los niños. Resulta ser lo natural frente a lo artificioso. Lo que hace elevada a una lengua son las ideas y emociones que nosotros ponemos en ella. De ahí que el poeta intentara dignificar el castellano poniendo ritmo en sus palabras y llenándolas con los más altos conceptos, los religiosos. Curiosamente, encontramos en esta defensa de la lengua vulgar una defensa de la igualdad de todas las lenguas. Parece que las diferencias de casta y linaje se habían puesto también a favor de las lenguas. Fray Luis apoya, de nuevo, la convicción de que las cosas y los hechos valen para lo que ellos son en sí mismos. No hay lenguas para decir cosas elevadas y lenguas para decir conceptos vulgares. En todo caso, la forma del decir es lo que debe cambiar. Lo humilde ha de decirse con llaneza y lo grave con palabras apropiadas ${ }^{62}$ : «Mas en lo que toca a la lengua, no hay diferencia, ni son unas lenguas para decir unas cosas, sino en todas hay lugar para todas» ${ }^{63}$. Lo que importa es ir a la realidad interna y auténtica. Lo exterior no es más que el ropaje de lo que las cosas son. Fray Luis, como en todos los hechos de su vida, se convierte en defensor de lo sencillo y lo humilde frente a la hipocresía y la altivez. El poeta quiere levantar a la lengua romance del decaimiento ordinario en que estaba. Es muy conocido el párrafo de la dedicatoria del libro $3 .^{\circ}$ que nos indica esto:

«El cual camino quise yo abrir, no por la presunción que tengo de mí, que sé bien la pequeñez de mis fuerzas, sino para que los que la tienen se animen a tratar de aquí adelante su lengua como los sabios y elocuentes pasados, cuyas obras por tantos siglos viven, trataron las suyas, y para que la igualen en esta parte que le falta con las lenguas mejores, a las cuales, según mi juicio, vence ella en otras muchas virtudes» ${ }^{64}$.

Apunta Fray Luis que Platón escribió cosas no vulgares en su lengua vulgar, y lo mismo Cicerón. Y continúa:

«... y por decir lo que es más vecino a mi hecho, los santos Basilio y Crisóstomo y Gregorio Nacianceno y Cirilo, con toda la antigüedad de los griegos, en su lengua materna griega, que, cuando ellos vivían, la mamaban con la leche los niños y la hablaban en las plazas las vendedoras, escribieron los misterios más divinos de nuestra fe...» ${ }^{65}$.

Helen Dill Goode, en el libro citado, estudia cómo Fray Luis intenta dignificar la lengua romance a base de la cláusula retórica romana; a nosotros lo que nos interesa es apuntar el trasfondo ideológico que hay detrás de todo ello. En toda esta defensa de la lengua romance hay la convicción de que lo

62. V.: Helen Dill Goode, «La prosa retórica de Fray Luis de León en Los Nombres de Cristo». Madrid 1969.

63. Op. cit. 656.

64. Op. cit. 658. Dedicatoria L. III.

65. Op. cit. 657. Ibidem. 
nacido del pueblo es lo bueno y honesto. La lengua romance es un elemento de igualdad entre todas las clases sociales del momento. Si Fray Luis no podía tolerar las absurdas diferencias de casta o de riquezas, tampoco podía permitir las diferencias en el orden intelectual, cuando éstas pretendían proceder de algo tan exterior como es la lengua que se usa. El necio, viene a decir, no deja de serlo por hablar latín. Lo que importa es lo que nosotros somos y pensamos. La lengua romance es elemento de unidad entre todas las gentes de España. Elevarla será elevar nuestra propia historia y nuestro ser de españoles por encima de las diferencias de raza, religión y situación social.

A Fray Luis le encanta el sentido aforístico de là sabiduría popular. Cuando va a tratar del estado del matrimonio, lo hará comentando un capítulo del libro de los Proverbios. A pesar de la procedencia culta de esta obra, tenía que recordarle a nuestro poeta el sabor de las cosas del pueblo. Estaba en el ambiente la estima de los refranes y los dichos populares. De nuevo vemos que el escritor se apropia de la estética profana para traducirla a lo divino, y así conseguir sus fines religiosos o morales. El refrán, el proverbio, el aforismo significaban una vuelta a lo más hondo del hombre, a la fragua donde el pueblo concentra la materia intelectual. Erasmo había consagrado en sus «Adagia» la categoría artística y conceptual de los refranes. En Salamanca, por los tiempos de estudiante de Fray Luis, el catedrático de la Universidad, Hernán Núñez se dedicaba a recoger cuantos refranes podía. Al entrar ya en edad avanzada y no poderlos glosar él mismo, los reunió por orden alfabético. En 1555 se publicaron con un prólogo de León de Castro en el que se exalta la significación de la sabiduría popular del refrán. Las diatribas contra los clérigos recogidas en esta selección de Hernán Núnez muestran claramente su erasmismo. Mal Lara escribe su «Filosofía vulgar» en plena Contrarreforma. Al escoger un capítulo de los Proverbios, Fray Luis se deja llevar de su devoción a la Biblia y de su entusiasmo por todo lo que indique un pensamiento concentrado, al estilo de la sabiduría del pueblo. Y los Proverbios se acercaban a ella como ningún otro libro bíblico. Fray Luis encuentra que, por medio de ellos, la inspiración del Espíritu Santo llega hasta las cosas más sencillas. De esta forma, Dios viene a andar entre los pucheros, como en la vida de santa Teresa. Es continuo este afán por santificar los hechos mínimos de la vida de los hombres. Dios se encuentra entre los humildes y sus cosas. Por eso anota el poeta que en las Sagradas Escrituras la Sabiduria divina enseña todo aquello que es propio de cada estado «y desciende tanto a lo particular de él, que llega hasta, entrándose por sus casas, ponerlas la aguja en la mano y ceñirles la rueca y menearles el uso entre los dedos» ${ }^{66}$.

Muchas de sus frases tienen la impronta de la sabiduría popular. En algunas ocasiones podemos incluso detectar la huella de Erasmo, como en el capítulo noveno de La Perfecta Casada donde nos dice que «lo que no se ve,

66. Op. cit. 234. Intr. La Perfecta Casada. 
no se desea; que, como dice el versillo griego, del mirar nace el amar». El dicho pertenece a la estética platónica y está tomado de los «Adagia» de Erasmo, Cent. 2, n. 79.

Espigamos algunos de los refranes que hemos anotado. Fray Luis defiende la crianza de los niños por las mismas madres, porque no se sabe cómo serán las amas de cría «Y si los hijos salen a los padres de quien nacen, ¿cómo no saldrán a las amas con quien pacen, si es verdadero el refrán español?» ${ }^{67}$. En el nombre de «Brazo de Dios» Fray Luis parece atacar la construcción de El Escorial, y dice «Y cuando suben, como dicen, el agua por una torre, entonces se tienen por la misma prudencia...» ${ }^{68}$. Le gusta citar el adagio «Alvar ro tam deest quod adest quam quod non adest» ${ }^{69}$. En el capítulo quinto del Cantar de los Cantares el Espíritu Santo reprende a los jóvenes «que se dan siempre al buen tiempo y se andan, como dicen, a la flor del berro, desacordados de que está por venir y les puede suceder» ${ }^{70}$. Y en el mismo capítulo Fray Luis recoge una bellísima expręsión de la lengua romance para calificar a un hombre apuesto: «En nuestro castellano, loando a uno de bien dispuesto, suelen decir dispuesto como un pino doncel».

El gusto por la espontaneidad y sencillez del lenguaje se muestra en el juicio que dio sobre la obra de santa Teresa. Al comentarla, dice que el lenguaje de la Madre Teresa es la misma elegancia, a pesar de los anacolutos que él mismo ha observado:

"Que aunque en algunas partes de las que escribe, antes que acabe la razón, la mezcla con otras razones, y rompe el hilo, comenzando muchas veces con cosas que injiere, más injiérelas tan diestramente y hace con tan buena gracia la mezcla que ese mismo vicio le acarrea hermosura, y es el lunar del refrán»" ${ }^{72}$.

Es significativo que Fray Luis, tan interesado en elevar el rango del castellano, se entusiasme y vea gracia y hermosura en el lenguaje de santa Teresa, paradigma de naturalidad y espontaneidad.

\section{c. La belleza y el aseo}

Con frecuencia se ha tachado a Fray Luis de antifeminista por las duras expresiones de La Perfecta Casada, especialmente; hoy en día resulta completamente anacrónico la diatriba que lanza el escritor contra los cosméticos que las mujeres han usado en todas las épocas. Al tratar del Comentario del Can-

67. Op. cit. 328. La Perfecta Casada, 17.

68. Op. cit. 536. Brazo.

69. Op. cit. Opera I, 397, 410,416.

70. Op. cit. 149. Cantar, 5,16 .

71. Op. cit. 149. Cantar, 5,16.

72. Op. cit. 1.316. "Carta-Dedicatoria a la madre Ana de Jesús». 
tar de los Cantares ya vimos cómo Fray Luis entiende la belleza, al estilo platónico, como una gracia interior unida a la justa proporción de las facciones exteriores. Detrás de las diatribas que el escritor hace contra los afeites y cosméticos de la mujer hay que ver una forma de comprender la realidad y unos principios estéticos fundamentales. No es fácil de mantener la acusación de antifeminista contra un escritor como Fray Luis que dedicó tres de sus cinco obras en castellano a mujeres: La Exposición del Cantar de los Cantares, a una monja del convento del Sancti-Spiritus, de Salamanca, Isabel Osorio; La Perfecta Casada a doña María Valera Osorio, y la Exposición del Libro de Job a la M. Ana de Jesús, la continuadora de la obra de santa Teresa, a quien tanto exaltó nuestro poeta.

No cabe duda de que en el Tratado de la Perfecta Casada aflora con frecuencia el predicador moralista que el escritor lleva dentro, sin embargo, por lo que se refiere a la belleza femenina, Fray Luis se expresa en la misma línea de pensamiento que le había hecho alabar lo rústico y lo auténtico y natural de las cosas. El poeta piensa que la naturaleza es superior al arte, $y$, por ello, juzga que todo añadido al rostro femenino destruye su verdadera hermosura. Al mismo tiempo, como todos los humanistas y pedagogos del XVI, defiende la higiene y la limpieza personal. Si la hermosura consiste en la justa proporción de los elementos, se concluye que «éstas de quienes hablamos, añadiendo posturas y excediendo lo natural, en caso de que fuesen hermosas, se tornan feas con sus mismas manos» ${ }^{73}$. En otro lugar afirma claramente que la belleża consiste en la proporción de figuras y en la limpieza y el aseó, porque, sin lo limpio, no hay nada hermoso ${ }^{74}$. Y que las gentes de entonces no debían lavarse mucho, lo muestran los consejos que da a las damas para mantenerse hermosas ${ }^{75}$.

El aseo y el orden debían ser parte del mismo Fray Luis. Al estar en la cárcel pide unos libros y da noticias exactas de cómo son y en qué lugar están. Así, al pedir su hábito, indica que «quedó en los cajones que están debajo de la mesa grande». También un Píndaro en griego y latín, de octavo, «en papelón y cuero negro, dorado de corte, quedó en uno de los cajones de la mesa grande». El cuidado y el orden debían ser extremados en Fray Luis. Al pedir una Biblia hebrea, impresa por Plantino y encuadernada en pergamino y cintas de seda, indica que «el un cuerpo está sobre la mesa y los tres envueltos en un papel en los cajones altos de la mesa grande, en el primer cajón comenzando por la ventana» ${ }^{76}$. Es realmante encantador este espíritu de orden y observación. El tenía fama de ordenado y pulcro. Para Juan Huarte de San Juan este cuidado que los estudiantes y los hombres pulidos tienen en sus habita-

73. Op. cit. 293. La Perfecta Casada, 11.

74. Op. cit.-335. La Perfecta Casada, 19.

75. Ib., 314. Ib., 12.

76. Documentos inéditos, T. X, pág. 388. 
ciones y de sus libros, "cada cosa en su lugar y en su clavo colgada» proviene de la facultad imaginativa, es decir, de aquella que es específica del poeta.

Fray Luis tenía que proclamar la superioridad de la naturaleza sobre el arte. Así se volvía a lo primitivo de las cosas. En la belleza no concibe que el arte pueda ayudar a la naturaleza, sino todo lo contrario. Mucho más cuando la belleza auténtica está en el interior, porque, entonces, es añadir obstáculos a la hermosura verdadera. No se puede tocar la obra de Dios. Hay que dejar a la naturaleza obrar. Ella es lo mejor que hay en la tierra. La misma idea estética subyace en estos ataques contra la coquetería femenina y el retorno a lo rústico, a lo pastoril y a la vida del campo. Lo natural es el producto primero de Dios. Y así hay que dejarlo. Atentar contra ello, tratar de cambiarlo, es perturbar la armonía establecida. En definitiva, es procurar el no ser frente al ser auténtico de las cosas:

« $i$ Y osa alguna mudar en otra figura lo que Dios hizo? Las manos ponen en el mismo Dios cuando lo que formó lo procuran ellas reformar y desfigurar; como si no supiesen que es obra de Dios todo lo que nace, y del demonio todo lo que se muda de su natural» ${ }^{77}$.

Aquí está la verdadera solución teológico-filosófica a todas las ideas éticas y estéticas de Fray Luis sobre la primacía de lo natural frente a lo artificial. Lo primero es obra de Dios; lo segundo del diablo. Hay una frase llena de sentido que, en otro filósofo cualquiera del Renacimiento podría ser tomada como panteísta, pero que en Fray Luis nos confirma en nuestra opinión respecto a su pensamiento sobre la belleza y lo natural: «la mujer que quiere hacerse otra figura (dice el poeta), toca al mismo Dios».

\section{La naturaleza como «Mayordoma de Dios»}

La última frase que hemos citado en el párrafo anterior suena muy fuerte a nuestros oídos. En muchas ocasiones nos da la impresión de que encontramos en la obra de Fray Luis recuerdos de aquella forma renacentista de ver la naturaleza dotada de un poder inmanente, cuya mejor expresión la dio Cervantes en el «Persiles y Segismunda»: la naturaleza es la «mayordoma de Dios». Nuestro poeta concibe a la naturaleza como engendradora de todo lo existente. Es una metáfora que encontramos varias veces en su obra. La naturaleza aparece como dando órdenes a las cosas y a los elementos que viven en la tierra:

«Mas como entre las cosas que son haya unas de vida limitada y otras que permanecen sin fin, en las primeras ordenó la naturaleza que engendrasen y tuviesen hijos, para que en ellos, como en retratos suyos, y del todo semejantes a ellos, lo corto de su vida se extendiese...» ${ }^{78}$.

77. Op. cit. 296. La Perfecta Casada, 11.

78. Op. cit. 666. Hijo. 
El concebir la naturaleza como un poder inmanente había comenzado en el siglo XV. Esto no significa una divinización, pero se encuentra en el mismo camino, aunque las conclusiones sean muy distintas. Procede, en último término, de la importancia que la naturaleza adquiere en el XVI. Se rompe la sumisión absoluta del Medioevo. En la idea de la naturaleza como «mayordoma de Dios», Este no se encuentra en cada hecho inmediatamente, sino mediatamente, a través de la fuerza que dio a la naturaleza para que actuara. Por eso la tierra es engendradora de todo lo existente. De ella sale el hombre y a ella tiene que volver. Aquí surge una pregunta honda, existencial, que entraña una rebelión sometida: ¿Cómo comprender que la naturaleza, madre y proveedora diligente, criase al hombre tan inclinado el mal?» ${ }^{79}$.

La naturaleza conduce a las cosas a sus fines. Así «dentro de ella declara casi a voces su voluntad, enviando luego después del parto leche a los pechos...", nos dice en la Perfecta Casada ${ }^{80}$. La naturaleza reparte el placer y el dolor para que las cosas tiendan a sus objetivos ${ }^{81}$. Y terminamos con unos endecasílabos de «Esperanzas burladas».

Mudó su ley en mí naturaleza, y pudo en mí dolor lo que no entienciu ni seso humano ni mayor viveza.

Fray Luis era hijo de su tiempo y siente sobre sí el peso de la estética y el pensamiento de la época.

79. Op. cit. 513. Ded. L. II. Nombres.

80. Op. cit. 331. La Perfecta Casada, 17.

81. Op. cit. 332. Ibidem. 